\title{
Biocrystals in Plants: A Short Review on Biomineralization Processes and the Role of Phototropins into the Uptake of Calcium
}

\author{
Mayra Cuéllar-Cruz ${ }^{1, *(\mathbb{D})}$, Karina Sandra Pérez ${ }^{2}{ }^{(0)}$, María Eugenia Mendoza ${ }^{3}$ \\ and Abel Moreno $2, *$ (D) \\ 1 Departamento de Biología, División de Ciencias Naturales y Exactas, campus Guanajuato, \\ Universidad de Guanajuato, Noria Alta s/n Col. Noria Alta, Guanajuato 36050, Mexico \\ 2 Instituto de Química, Universidad Nacional Autónoma de México, Av. Universidad 3000, \\ Ciudad Universitaria, México City 04510, Mexico; ianaks000@gmail.com \\ 3 Instituto de Física, Benemérita Universidad Autónoma de Puebla. Av. San Claudio y 18 Sur, \\ Ciudad Universitaria, Puebla 72570, Mexico; emendoza@ifuap.buap.mx \\ * Correspondence: mcuellar@ugto.mx (M.C.-C.); carcamo@unam.mx (A.M.)
}

Received: 15 June 2020; Accepted: 8 July 2020; Published: 9 July 2020

\begin{abstract}
The biomineralization process is a mechanism inherent to all organisms of the Earth. Throughout the decades, diverse works have reported that the origin of life is tied to crystals, specifically to biominerals of silica that catalyzed RNA, and had some influence in the homochirality. Although the mechanism by which crystals surfaces (minerals) gave origin to life has not yet been proven, the truth is that, up to the present, biominerals are being synthetized by the organisms of different kingdoms in two basic ways: biologically induced and biologically controlled biomineralization. Paradoxically, this fact makes a fundamental difference between inorganic materials and those formed by living organisms, as the latter are associated with macromolecules that are bound to the mineral phase. Conserving growth and formation of these biogenic organic crystals inside cells is a fascinating subject that has been studied mainly in some of the kingdoms, like Monera (bacteria), Fungi (yeasts), and Animalia (Homo sapiens). Notwithstanding in the Plantae kingdom, the formation, conservation, and functions of crystals has not yet been completely elucidated and described, which is of particular relevance because life on Earth, as we know it, would not be possible without plants. The aim of the present work is to revise the different crystals of calcium oxalate synthetized inside the cells of plants, as well as to identify the mechanism of their formation and their possible functions in plants. The last part is related to the existence of certain proteins called phototropins, which not only work as the blue-light sensors, but they also play an important role on the accumulation of calcium in vacuoles. This new trend is shortly reviewed to explain the characteristics and their plausible role in the calcium uptake along with the biomineralization processes.
\end{abstract}

Keywords: crystallization of proteins; crystallization of macromolecular complexes; in vivo crystals; organisms of the different kingdoms; calcium uptake; phototropins

\section{Introduction}

The synthesis of biogenic crystals is perhaps the most ancient chemical process linked to the origin, evolution, and conservation of life on Earth. The possible role of minerals as catalysts in the polymerization of monomers to polymers of organic molecules (RNA) essential for the origin of life was proposed six decades ago by Bernal (1949) [1]. Since then, several studies have reported experiments showing that the origin of life is linked to either crystals or biominerals. There are works indicating that life started with pyrite, which, due to its positive charge on the surface, can agglomerate 
biomolecules with negative charge that would become organized, forming large organic chains in the evolution that would be transformed into complex organic molecules [2,3]. Some authors describe that montmorillonite [4], hydroxyapatite, illite [5], and even other minerals are responsible for the catalysis of diverse organic molecules [6-8]. Interestingly, one of the reported works indicates that the first living organisms were of mineral origin and that the first genes were crystalline [9]. Besides, it is speculated that these crystalline genes should be able to store a large amount of information and to transmit it through crystalline growth processes. This proposal infers that clay would be the crystal that fulfills the characteristics of being a crystal-gene, because it is similar to the proteins or DNA formation. Besides, it presents many defects in its structure, defects that can evolve and be transmitted to successive generations, which could be considered as a model of primary genetic transmission [9]. As a whole, these works suggest that, apparently, minerals fostered the chemical processes that gave rise to biogenesis. Although the mechanism by which crystals gave origin to life has not yet been confirmed, it is true that, up to the present, organisms of the different kingdoms continue to synthetize crystals. A fact that, paradoxically, makes a fundamental difference between inorganic materials and those formed by living organisms, as the latter are associated with macromolecules bound to the mineral phase. Among these macromolecules are important organic molecules such as amino acids, sugars, and other molecular species that formed crystals in the organisms of the five kingdoms. Both the organic and inorganic crystals play relevant roles in the formation and conservation of life [10]. For example, in bacterial cells, crystals formed by iron, named magnetite crystals, exert magnetic and storage functions and capture iron as a reserve of electron acceptors or donors [11]. In addition, proteins participate in the synthesis of these magnetite crystals [12]. Another type of crystals widely reported in diverse organisms are the calcium salts crystals, which are found in avian eggshells, fungi, plants, and animals. Most of these crystals serve as protection, defense, support, or sensors [13-28]. A unique characteristic of the synthesis of these crystals is that it is mediated by proteins [19]. Although a considerable amount of inorganic-type crystals has been reported to form mainly the cellular structure, the crystals synthetized within the cells, whose chemical composition is made of biomacromolecules, like proteins, carbohydrates, nucleic acids, and other organic molecules, are of special interest, because their presence inside the cells is bound to biological functions $[19,29]$. There are biominerals found in contact with these biological macromolecules, these are hybrid nanocomposites where proteins, polysaccharides (chitin, collagen and other sugars) are chemically associated with a variety of calcium salts namely calcium oxalate, calcium phosphate and calcium carbonate. All these inorganic-organic hybrid materials are creating smart and functional materials that give new ideas for future applications in science (biomimetics) [30]. Some biominerals like calcium oxalate can also be used in materials science with specific applications to preserve cultural heritage. The method consists of protecting surfaces of stone material or stone-based cultural relics and comprises cleaning the surface with a cleaning agent. This method already patented uses calcium oxalate supersaturated solution to be crystallized on the surface to form a calcium oxalate protective film [31].

On the other hand, calcium phosphate and hydroxy apatite are very important biominerals, which are present in bones and teeth formation in higher animals. Calcium phosphate biominerals are also involved in urolithiasis [32]. Particularly in plants, the presence of calcium phosphate has not been extensively investigated. The first observations were done recently on plant trichomes, where calcium phosphates are often replaced by silica [33,34]. The intriguing discovery about the existence of hydroxyapatite as structural biomineral in plants (loasaceae-plants-teeth), as way of protection against herbivores, has been recently investigated [33]. Conservation of the growth and formation of these organic crystals inside the cell is a fascinating topic that has so far only been studied in some of the kingdoms, like the Monera (bacteria), Fungi (yeasts), and Animalia (Homo sapiens) [10,16,19]. However, in the Plantae kingdom, the formation, conservation, and functions of crystals has not yet been fully elucidated or described, which is of particular relevance as life on earth, as we know it, could not be possible without plants. Some of the important functions of plants are: (i) to provide food to almost all terrestrial organisms; (ii) to maintain in equilibrium the atmosphere of the Earth by 
producing oxygen and displacing enormous amounts of water from the soil to the atmosphere; (iii) to maintain the cycle of water and nutrition of soils; (iv) to contribute to the nitrogen cycles and other biogeochemical cycles; (v) to keep interdependence with animals, microorganisms, and among plants; and (vi) to release large amounts of carbon dioxide to the atmosphere. At a global level, it has been calculated that plants release, as a product of respiration, approximately 60 gigatons of carbon per year to the atmosphere, which, in turn, is exploited by the rest of the organisms [27]. A very important topic that deserves to be taken into account is the process of silica deposition and biosilicification either in animals or in plants. These silica biogenic minerals whose name has been coined as biolites in general have specific nomenclature namely zoolites in animals and phytolites in plants. These biolites have also specific names depending on the mineralizing agent, if there is calcium carbonate these are called calcibiolites, whereas if there is amorphous silica, these are called silicobiolites (or phytolites). Phytolites, in particular, were discovered for the first time by Christian Gottfried Herenberg in 1854, but the precise understanding and research of their formation as well as the role of proteins involved in the biosilicification is still scarce. These topics, as well as the first approaches to understand their formation and their biomineralization mechanisms, have been recently reviewed [35]. The physiological and ecological significance of these biomineralization processes in plants, as well as an overview on the problem of vital effect, have also been revised few years ago [36,37].

The objective of this work was to perform a review of the different crystals synthetized inside the cells of plants, specifically calcium oxalate (CaOx) crystals, as well as to elucidate the mechanism of formation and the possible functions of these crystals in the plant. Additionally, in the last part, we have shortly revised topics related to the existence of certain proteins called phototropins found in many plants. These are promising blue-light biosensors that play an important role in the uptake of calcium into the biomineralization processes.

\section{Calcium Oxalate Crystals Synthesized in Plants}

Crystals produced by plants are the final products of cellular metabolic processes, which usually are deposited in vacuoles and cytoplasm. The most common inorganic crystals are constituted by calcium salts, like calcium oxalate and calcium carbonate [26]. Other crystals that are also found in plants are silica ones, which are present in the cell wall of Gramineae plants. Crystals are found in diverse geometrical shapes, which are characteristic of each species or of higher taxonomic groups, thus, some authors consider that they could be useful as classification and taxonomic identification criteria [25]. Plants that generate oxalate crystals are classified in two categories, those containing soluble oxalates and those containing insoluble oxalates. Soluble oxalates include oxalic acid and sodium, potassium, and ammonium oxalates. Some of the plants in which the production of soluble oxalates has been reported are Averrhoa carambola L, Parthenocissus tricuspidata, Rumex crispus, Halogeton glomeratus, Oxalis tuberosa, Rheum rhabarbarum. However, plants that contain insoluble oxalates are those that produce crystalline needles of calcium oxalate called raphides. Our present work is focus on these plants. Interestingly, the generation of insoluble crystals produced by plants has been proposed as a defense mechanism against herbivore animals, because when these animals chew on these plants, the crystals produce small injuries in the mucosa inducing severe irritation. Another way of damaging herbivores is through crystals containing enzymes with antitrypsin activity that stimulate the release of histamine and bradykinin, because these crystals puncture and lesion the cellular structures accompanied by the release of vasodilating agents that lead to edema and congestion. The plants that produce insoluble oxalate crystals are: Agave, Alocasia spp., Arisaema triphyllum, Caladium spp., Colocasia, Difenbachia spp, Monstera, Oxalis, Philodendron, Symplocarpus, Xanthosoma, Zantedeschia aethiopica, Epipremnum aureum, Spathiphylum, Syngonium, Anthurium, Aglaonema, Begonias [25-27].

\subsection{Soluble Crystals: Oxalic Acid and Sodium, Potassium, and Ammonium Oxalate}

The name of the oxalic acid derives from the genus of the Oxalidaceae family of plants and was identified for the first time in sorrels by the chemist and botanist Herman Boerhaave in 1745. Later 
on, it was isolated from Oxalis acetosella in 1773 by Francois Pierre Savary [27,28]. Currently, several mechanisms have been described through which plants synthetize oxalic acid. One of these pathways is through glycolate, which can be converted to oxalic acid. Another synthesis mechanism derives from the rupture of oxaloacetate or ascorbic acid [27,29]. The oxalic acid reacts with cations resulting in the formation of different crystals of oxalate, which has been considered to be related with the maintenance of ionic equilibrium [29]. Plants of the Oxalidaceae family in which synthesis of oxalic acid crystals has been reported are varied; for example, Averrhoa carambola is a popular plant native to Asia, in which a high concentration of oxalic acid has been identified [38,39]. This plant has been associated with the diseases caused in people consuming it; among these diseases are acute nephropathy by oxalate and the direct renal tubular damage through the release of free radicals, which are the main mechanisms involved in the acute renal injury (ARI) induced by A. carambola [38]. Oxalic acid is also produced in other plants like Spinacia oleracea, Rumex acetosa, Apium graveolens, Daucus carota, Brassica oleracea var. italica, Brassica oleracea var. capitata. From the oxalic acid, plants synthetize both the soluble oxalate (sodium, potassium, ammonium oxalate) and the insoluble ones (calcium oxalate) [38-41].

\subsection{Insoluble Oxalates: Calcium Oxalate}

Calcium oxalate $(\mathrm{CaOx})$ crystals are considered common compounds that are found in diverse groups of plants. The $\mathrm{CaOx}$ crystals are found in algae, angiosperms, and gymnosperms, in a total of more than 215 families [42,43]. These plants accumulate $\mathrm{CaOx}$ through a biomineralization process in diverse ways. It has been described that these crystals are formed mainly in the intra-vacuolar membrane or in the chamber of specialized crystalline cells known as idioblasts [44-48] (Figure 1).

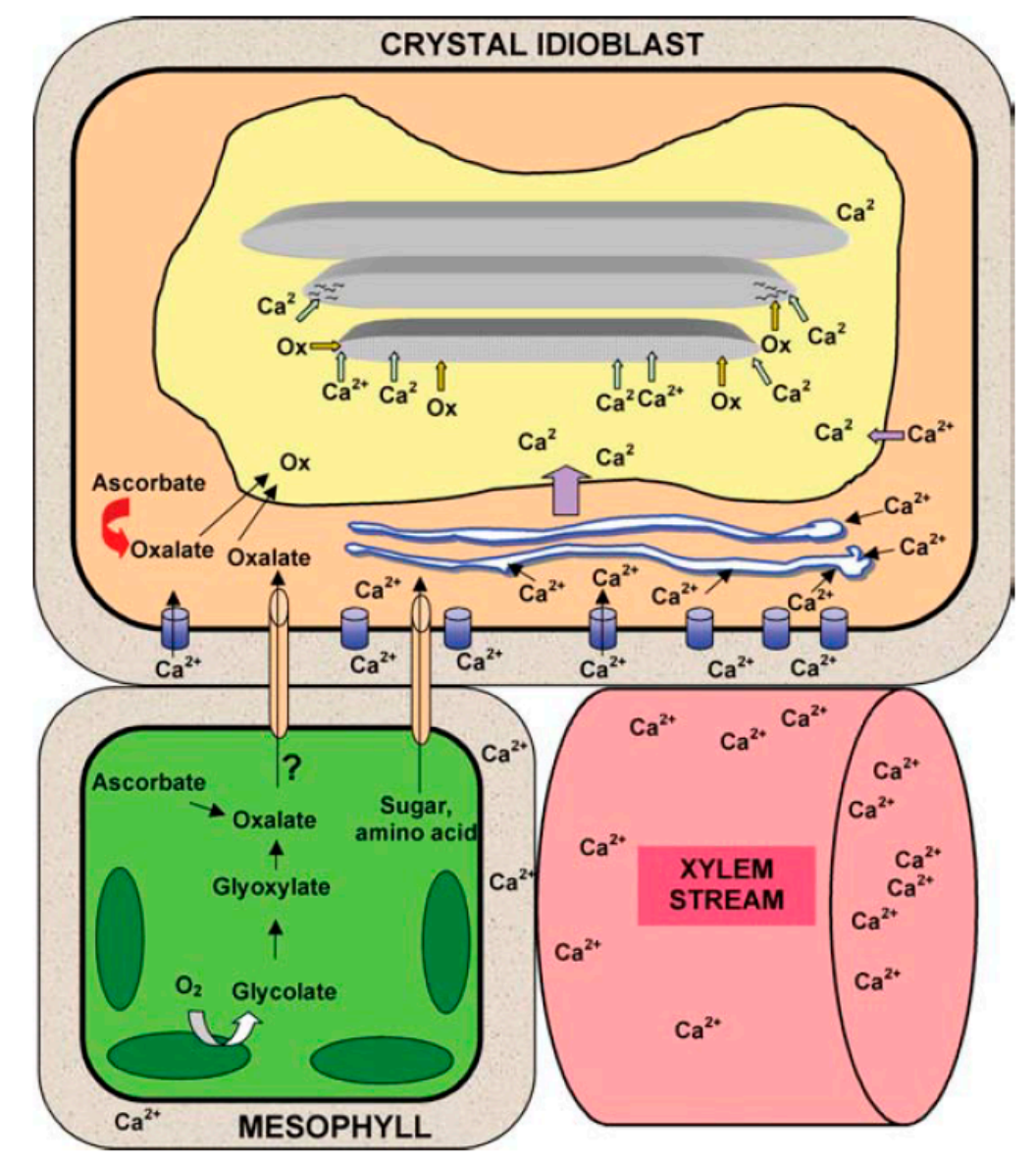

Figure 1. Mechanism of the formation of calcium oxalate crystals in idioblasts. Modified from Franceschi and Nakata (2005) [48]. With permission from Annual Review of Plant Biology. 
The synthesis of crystals is associated with membranes, chambers, or inclusions found inside cellular vacuoles, as well as with proteins, such as calsequestrin, whose function is to regulate the activity of the cytosolic calcium before it is stored in the vacuoles [27,29,49]. It has been reported that the CaOx crystals are able to modify the tubules, plastids, and to enlarge the nuclei of idioblasts [50]. The synthesis of $\mathrm{CaOx}$ crystals starts with ascorbic acid, which gives rise to oxalic acid. Once the adequate concentration of oxalic acid has been reached, the oxalate oxidase is activated, which acts as a regulator of oxalic acid and participates in the formation of oxalate crystals [51-54]. CaOx crystals present different morphologies, which can include raphides, druses, styloids, prisms, and crystal sand [50], the most common ones are raphides and druses (Figure 2).

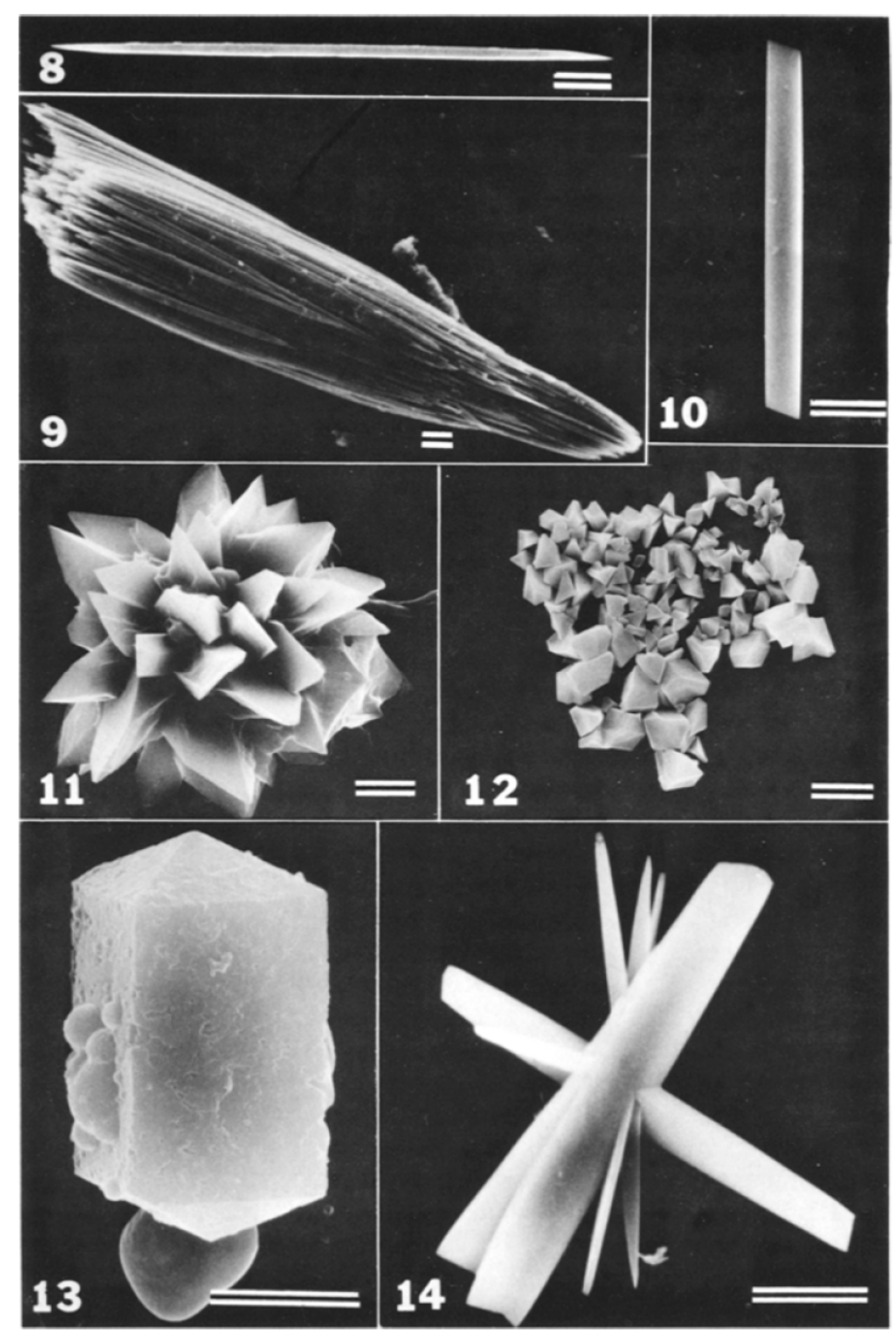

Figure 2. This figure shows a collection of the most typical morphologies published elsewhere of diverse $\mathrm{CaOx}$ crystals, prisms, sand, raphide, and druses. Single raphide crystal from leaf raphide bindle of Psychotria puntata. 8 and 9: Leaf raphide crystal bundle of Psychotria puntata. 10: Styloid crystal from leaf spongy parenchyma of Peperomia. 11: Druse crystal from leaf of Opuntia sp. 12: Crystal sand from petiole of Nicotiana glauca. 13: Prismatic crystal from leaf of Begonia sp. 14: Aggregate crystal complex from leaf spongy parenchyma of Peperomia astrid. Microphotographs from Franceschi and Horner Jr., 1980 [50], reproduced with permission.

Some authors describe that the crystalline form adopted by CaOx crystals depends on the way in which they act on the membranes of the crystal chamber to mold its shape. Although the actual 
mechanism that regulates the shape has not been yet elucidated. Regarding crystals that depict the $\mathrm{CaOx}$ raphide shape, they generally present four faces, the form of an $\mathrm{H}$ with a groove on both sides, or a transversal hexagonal section, and some present spikes. The circular section of raphides are probably hexagonal in a transversal section [55]. One of the functions of $\mathrm{CaOx}$ crystals in the raphide shape is as defense mechanism of plants against predators, as they cut and injure tissues of the throat or esophagus of the predator when chewing on the leaves of the plant. Besides, some ornate plants that contain raphides, and which can be ingested accidentally by humans can cause painful edemas, formation of vesicles, and painful dysphagia accompanied by itching and burning in the mouth and throat, symptoms that can last up to two weeks. Some of the plants that synthetize raphides are: Alocasia, Arisaema, Arum, Schefflera, Caladium, Caryota, Colocasia, Dieffenbachia, Epipremnum, Fucsia, Monstera, Philodendron, Spathiphyllum, and Tradescantia. The other crystalline structure presented by CaOx crystals are druses. Formation of druses implies diverse biochemical routes for the biomineralization of $\mathrm{CaOx}$ in plants; rupture of L-ascorbic acid, hydrolysis of oxaloacetate, rupture of isocitrate and/or oxidation of glycolate/glyoxylate are the routes that have been described $[48,56]$. As in the formation of raphides, proteins, polysaccharides, membrane structures participate in the synthesis of druses. Druses are also found in the leaves and scales of the buds of plants, like Prunus, Roses, Allium, Vito, Morus, and Phaseolus. The poisonous substances in druses are a defense mechanism of plants against herbivores.

\subsubsection{The Cactaceae Family of Plants}

An interesting group of plants of the Cactaceae family contains high concentrations of $\mathrm{CaOx}$ crystals $[45,48,57,58]$. This family is native to the American continent; it is constituted by ca. 2000 species, distributed from northern Canada to The Patagonia, and from sea level, in costal dunes, to the high mountains in Peru [59]. This family is divided into four subfamilies: Pereskioideae (monogeneric, ancestral cactus), Opuntioideae (cushion-type cactus), Maihuenioidea (monogeneric), and Cactoideae (the one with the greater number of species) [45]. These plants are considered by the experts as a natural monophyletic group that has evolved in the last 80 million years and developed from non-succulent forms. An interesting trait of Cactaceae is the fascinating anatomy of their structures and tissues that have the capacity to store large amounts of water, which grants them a great adaptability to droughts. Ample studies have been performed in this family to evaluate the frequency of the different types of $\mathrm{CaOx}$ crystals aimed at determining whether they can be used as traits for Cactaceae systematics [45]. Extensive studies show the different types and composition of $\mathrm{CaOx}$ crystals presented by this family. In this way, it has been identified that the species of both Pereskioideae and Opuntioideae form calcium oxalate monohydrate (COM, whewellite), whereas the Cereoideae species form preferably calcium oxalate dihydrate (COD, weddellite). Although there are some exceptions, and some cacti species have shown the coexistence of whewellite and weddellite [45]. The morphologies presented by the COM type are generally monoclinic druses, monoclinic styloids (prism), raphide, rhomboid, and parallelogram, whereas the COD type are tetragonal druses, aspherical aggregates, tetragonal styloids (prism), and (bi)-pyramid [45,57]. Some of these morphologies are depicted on Figure 3. 

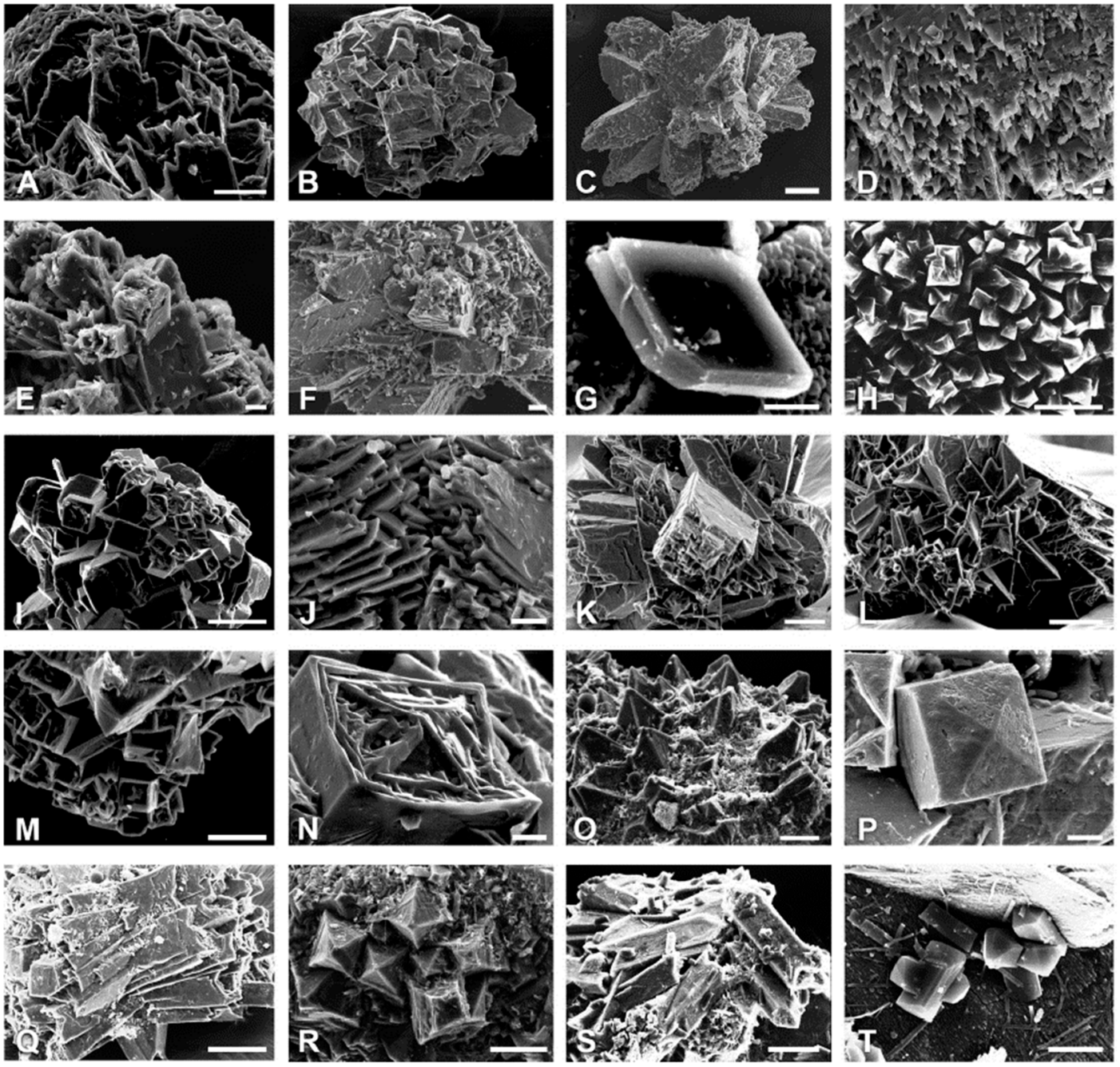

Figure 3. Morphologies of the CaOx crystals identified in Cactaceae. Microphotographs from Bárcenas-Arguello et al., 2015 [57] reproduced with permission. Crystal habits in species of Cephalocereus. A-F. C. apicicephalium, G-N. C. nizandensis, $\mathbf{O}-\mathbf{T}$. C. totolapensis. Bar is $25 \mu \mathrm{m}$ in $\mathbf{A}, \mathbf{F}, \mathbf{M}, \mathbf{O}, \mathbf{R}, \mathbf{S}, 100 \mu \mathrm{m}$ in $\mathbf{B}, \mathbf{C}, 10 \mu \mathrm{m}$ in $\mathbf{D}, \mathbf{E}, \mathbf{H}, \mathbf{J}, \mathbf{N}, \mathbf{P}, 2.5 \mu \mathrm{m}$ in $\mathbf{G}, 50 \mu \mathrm{m}$ in $\mathbf{I}, \mathbf{K}, \mathbf{L}, \mathbf{Q}, 5 \mu \mathrm{m}$ in $\mathbf{T}$.

Other Cactaceae species, like the vine cactus Hylocereus costaricensis and Selenicereus megalanthus, have been shown to be able to synthetize both mono- and di-hydrated $\mathrm{CaOx}$ crystals with different morphologies [58]. Other species within the Cactaceae family are Cephalocereus apicicephalium, C. totolapensis, and C. nizandensis, which are endemic to Mexico; interestingly, it was found that the $\mathrm{CaOx}$ crystals are of the weddellite type with different degrees of hydration [57]. The fact that these species present this type of polymorph is novel for this genus, as they can be used as a source of phylogenetic characters [57]. Other cactaceans in which $\mathrm{CaOx}$ crystals have been identified are Coryphantha clavata, Ferocactus latispinus, Opuntia ficus-indica, O. robusta, and O. strepthacantha [59]. In these species, through Raman spectra, it was possible to identify the chemical composition of the CaOx crystals; in the three Opuntia species, the crystals are formed by calcium oxalate monohydrate, whereas the species of $C$. clavata and F. latispinus form crystals of calcium oxalate dihydrate [59]. Mammillaria uncinata is an endemic biznaga species pertaining to the Cactaceae family found from the North to the South of Mexico. Through energy dispersive spectroscopy, IR and Raman spectroscopy, it has been shown that this species produces calcium oxalate dihydrate (weddellite) crystals $[60,61]$. 


\subsubsection{Fabaceae or Leguminosae Family}

Formation of $\mathrm{CaOx}$ crystals is a process that also occurs in fruits, seeds, grains, and vegetables. It is interesting how Gulliver, since 1873, showed the presence of crystals in the pericarp and testa of some Leguminosae or Fabaceae $[62,63]$. Prismatic crystals of $\mathrm{CaOx}$ have been identified in the subfamily Faboideae [64-72]. Beans are legumes that possess eatable seeds with the presence of CaOx crystals. This seed is distributed in the five continents. It has been proposed that the mechanism for the formation of crystals in the envelope of bean seeds involves participation of fibrillar material inside the vacuoles, as well as mitochondria and plastids. Development of crystals implies a thickening of the cell wall that makes contact with crystals and start their development [69]. By means of X-ray diffraction, crystals have been identified in the kidney bean, and it was determined that they correspond to the whewellite polymorph [62]. These crystals present an interesting morphology, as they are twin crystals. This type of crystals can be of two types; kinked and straight crystals. Crystals of this type exist in other plants, like Psychotria punctata, Peperomia sp., Opuntia sp., Nicotiana glauca, Begonia, Peperomia astrid, Quercus, Castanea, Fagus, Carpinus, and Ostrya [62].

$\mathrm{CaOx}$ crystals are also found in leaves and it has been shown that these crystals accompany the veins. The polymorph of these crystals is the calcium oxalate monohydrate (whewellite) [65], which is the same as that found in the seeds. Interestingly, it has been reported that the crystals in the bean play a relevant role in regulating the levels of bulk calcium [67]. Another species of the Fabaceae family is Glycine max L. (soybean), this plant is cultivated for its seeds of mid content of oil and high content of protein. This grain is commercialized worldwide due to its multiple uses. The presence of $\mathrm{CaOx}$ crystals has been observed in practically all organs, both vegetative and reproductive, of the soybean [61]. It has been reported that the formation of these crystals is due to an accumulation of calcium in the apoplast of cells [51]. The morphology of the crystals found in the different organs of the soybean varies. However, the crystals of the soybean sheath were smaller as compared to the crystals found in other vegetative and reproductive organs of the soybean [61]. It has been reported that this type of prismatic crystal morphology is produced when calcium transport is limited by the lignification of the cell walls [73]. Besides, it has been observed that the $\mathrm{CaOx}$ crystals found in young ovules before fertilization increased in the funiculus and inner integument in the young seed. As the embryo grew, crystals started to appear in the cotyledons and, in that moment, the crystals of the outer integument disappeared. Close to the mature seed, the crystals were observed only in the cotyledons and in the funiculus [74] (Figure 4).

Medicago is another genus of the Fabaceae family; it is formed by perennial plants with flowers known as bur-clovers. The most conspicuous member of this genus is Medicago sativa known commonly as alfalfa [75]. In this species, $\mathrm{CaOx}$ crystals have been identified in the parenchymatous sheath that envelopes the vascular bundle in the leaves. Crystals are produced on the surface of the leaf clusters, and they are less frequent and organized in the stems [76]. Medicago truncatula is another species in which CaOx crystals have been identified and analyzed. This plant grows around 10 to $60 \mathrm{~cm}$ of height with trifoliate leaves and it is used as an experimental model. It has been reported that the prismatic $\mathrm{CaOx}$ crystals produced by alfalfa are used as a defense mechanism against insect feeding, because the crystals have abrasive effects on the mandibles of insect larvae [77]. The CaOx crystals in M. truncatula accumulate predominantly in the sheath that surrounds the secondary veins of the leaves $[75,77]$. 

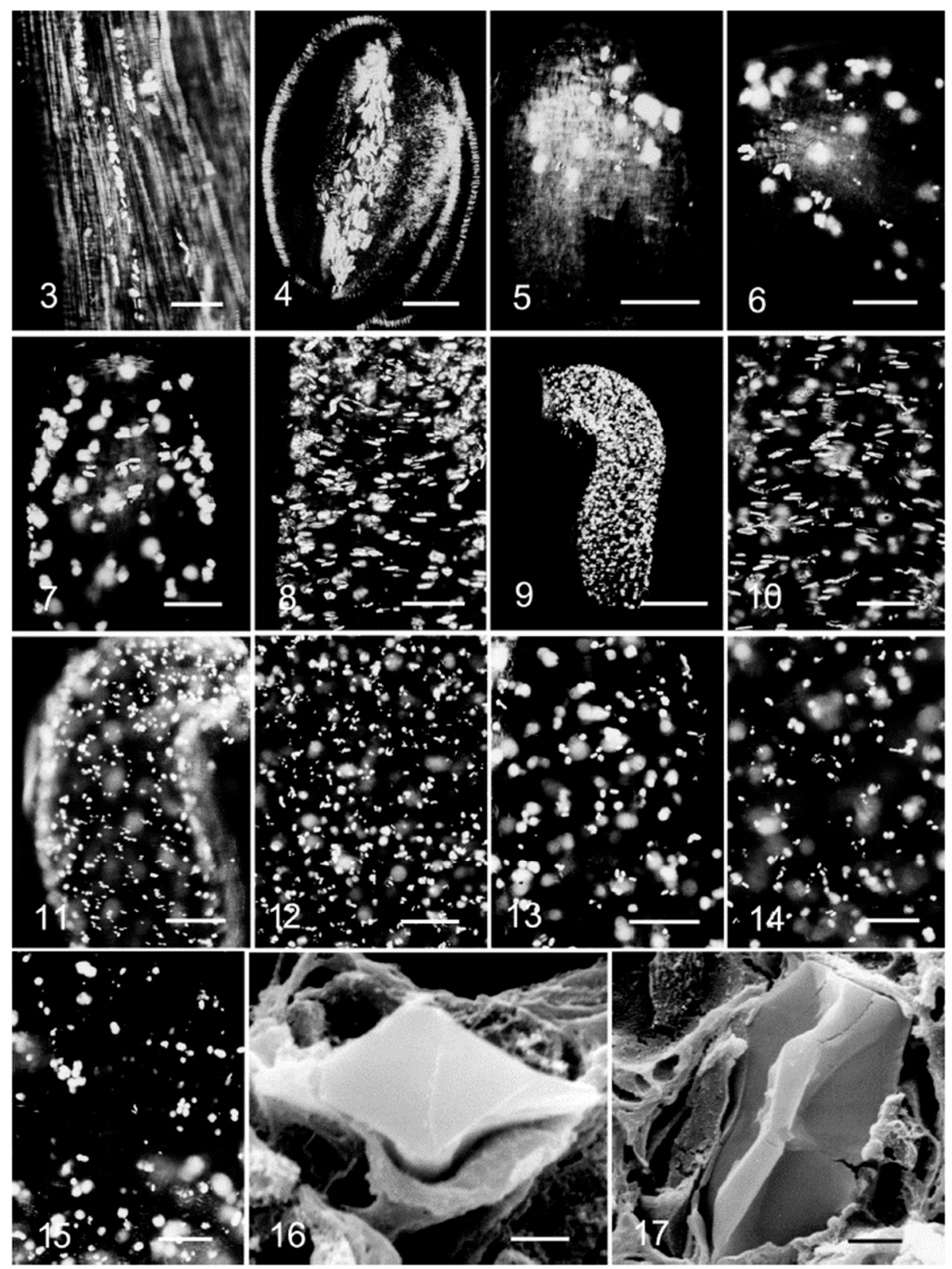

Figure 4. CaOx crystals in soybean. According to the original Figure the images correspond to (3) Ovary walls. (4) Anthers. (5) Youngest soybean ovules. (5-12) Embryo cotyledons 1 to 16 days (integuments). (13-15) Seeds from 24 to 60 days (cotyledons). (16) Fractured-open cell vacuoles and seen in cross-sectional view. (17) Longitudinal view. From Ilarslan et al. (2001) [74] reproduced with permission.

\subsubsection{The Gramineae or Poaceae Family}

The Gramineae or Poacea family is placed fifth among the largest families of the kingdom, with 780 genera and close to 12,000 species. It is considered that almost $40 \%$ of the terrestrial space is occupied by these species. They are found in all continents, except in Antarctica, and in both aquatic and terrestrial environments. Traces of this family have been found that go back to the Cretaceous period, since rests of grasses related to modern rice and bamboo have been found in fossils of that period. This information indicates that biomineralization is a fundamental process performed by the first cells that existed on Earth and, undoubtedly, this family of plants is capable of achieving it successfully. Some of the widely cultivated grasses are Zea mays (corn), Triticum (wheat), Hordeum 
vulgare (barley), Avena sativa (oat), Sorghum (sorghum), and Oryza sativa (rice). In the Z. mays species, commonly known as corn, the presence of crystals has been reported since 1903 [78]. The morphology of the described crystals corresponded to sphalerite, irregular crystalline aggregates, prismatic crystals, and double-pyramid shapes [79]. CaOx crystals have also been reported in the leaves of a bamboo (Bambusa stricta Roxb) [79]. Although species of this family have been described of being formed of $\mathrm{CaOx}$ crystals, there is scarce or nil information about the polymorph and the morphology of these crystals in the different species.

\subsubsection{Plants of Human Consumption That Produce Caox}

As mentioned, $\mathrm{CaOx}$ crystals have been found in most plants. Fruits and vegetables contain variable amounts of these crystals. It has been described that most are not harmful to health; however, some vegetal species can contain a higher concentration of crystals and can induce intoxication. A family of which some of its species are used to prepare alcoholic beverages, both fermented and non-fermented, is the Agavaceae. More than 200 species have been identified pertaining to this family; it is considered that this family appeared some 12 million years ago. One species of this family is the Agave tequilana Weber, from which tequila is obtained. The CaOx crystals characterized in this species depict styloid and raphide morphologies [80,81]. Another species of this family is Agave atrovirens, from this plant a fermented beverage is obtained called "pulque", CaOx crystals with the raphide morphology were identified in this plant [82]. Another species of great interest as food that is capable of producing $\mathrm{CaOx}$ crystals is Theobroma cacao L., which is the cacao tree. This plant pertains to the Malvaceae family, which is native to Mexico and its seed is considered as the food of gods. The presence of $\mathrm{CaOx}$ crystals has been reported in the seed of $T$. cacao on its outer endosperm epidermis [44]. The Solanaceae family is another family of interest as food source. Within this family is the Solanum lycopersicum species, commonly known as tomato. These species are widely spread in the American continent. In these species, it is common to find small yellow spots around the calix and on the upper part of the fruit. These spots have been found to correspond to CaOx crystals, presenting a raphide-type morphology, which are produced in large amounts in the pulp of tomatoes, which show numerous gold spots in their wall $[83,84]$. Another plant in which CaOx crystals have been reported is in the kiwifruit, in this the morphology corresponds to the polymorph whewellite [85]. Even though, in diverse fruits and legumes of human consumption, $\mathrm{CaOx}$ crystals have been identified as the causative agents of mouth irritation $[81,83,84]$, these works only characterize very superficially these crystals; it would be interesting to characterize the $\mathrm{CaOx}$ crystals in all fruits, grains, and seeds that are a fundamental part of the food network of higher organisms.

\subsubsection{The Araceae Family}

Aside from the plant families already mentioned, there are other plants that produce $\mathrm{CaOx}$ like ornamental plants, which, if not handled correctly, can cause local irritation or edema, because of the type of $\mathrm{CaOx}$ they contain. A family of ornamental plants is the Araceae, which comprises 104 genera and more than 3000 species. Among this family are those known as arum (Anthurium), calla (Zantedeschia), philodendron (Philodendron), and duckweed (Lemna) [86]. As mentioned, the crystals exert a protective function, in the case of the Araceae family, analyses have shown that the crystals protect the reproductive tissues, and these crystals participate in pollination. Interestingly, it has been found that the species of this family produce crystals with different morphologies (Figure 5) from those generated in the inflorescence of Amorphophallus titanum; besides, crystals mixed with pollen have been found in aroid species [87], a result indicating that the crystals protect the gametes and embryos from predatory insects [88]. 


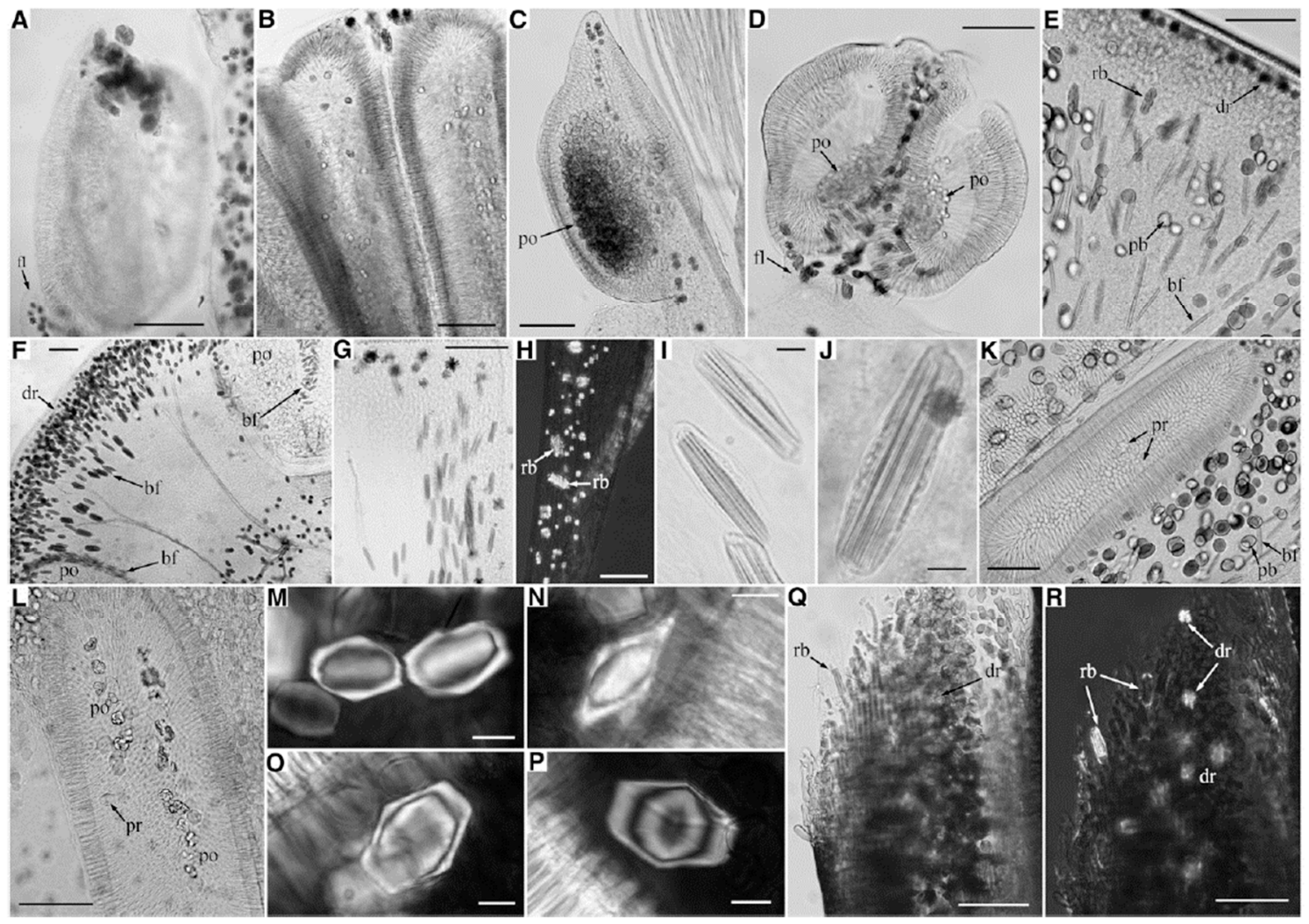

Figure 5. Crystals in male flower parts of aroids. (A-D) Species with free stamens. (E-R) Species with stamens fused into synandria. Figure from reference [88], reproduced with permission. Original figure legend: "Crystals in male flower parts of aroids. (A-D) Species with free stamens. (E-R) Species with stamens fused into synandria. (A) Stamen of Anthurium clarinervium. Filament at bottom left; raphide bundles visible at top, presumably in connective; gynoecium wall at right. (B) Stamen of Typhonium venosum; raphide bundles at top of connective. (C) Raphide bundles in fi lament and connective of stamen of Monstera obliqua. Pollen visible in anther; gynoecium wall at right. (D) Stamen of Pistia stratiotes; crystals in short fi lament and in connective between anthers. (E) Connective of synandrium of Caladium bicolor. Druses at top, and raphide bundles and biforine-like cells, mixed with pale, pigment-containing bodies below. (F) Connective of synandrium of Dieffenbachia seguine; anthers with pollen at upper right and lower left. Druses at top of connective; biforine-like cells below and alongside anthers. Moreover, note curving line of biforine-like cells running along the anther at upper right, and also (out of plane of focus) at lower left. (G) Connective of synandrium of Philodendron erubescens; outer surface at very top of picture, side surface at right edge. Druses at top, druses, and biforine-like raphide bundles below, especially at side. One large elongated bundle also visible near side, at lower right. (H) Druses and raphide bundles along the side of the connective of Ph. solimoesense. Crystals were difficult to see with bright-field illumination, because the pigment does not readily clear; therefore, they were visualized with polarization microscopy. (I) Close-up of biforines in connective of Ph. melinonii. (J) Close up of biforine and a druse behind it in connective of Syngonium podophyllum. (K) Anther of Caladium bicolor, connective at either side. Pigmented bodies and biforine-like cells in connective at lower right. Prisms barely visible in theca. (L) Anther of Xanthosoma sp, connective on either side. Prisms visible in theca. (M-P) Close ups of prisms mixed with pollen in thecae of (M) Dieffenbachia seguine, (N) Syngonium podophyllum, (O) Caladium bicolor, and (P) Xanthosoma sp. $(\mathbf{Q}, \mathbf{R})$ Chewed synandrium of $P h$. solimoesense, identical views under $(\mathbf{Q})$ bright-field illumination and $(\mathbf{R})$ polarization. Because this species does not bleach easily, crystals are poorly visible in bright field; many more crystals are visible by polarization. Micrographs $\mathbf{H}, \mathbf{M}-\mathbf{P}$, and $\mathbf{R}$ were imaged by polarization microscopy; all others are bright fi eld. Bar $=20 \mu \mathrm{m}$ on $\mathbf{I}, \mathbf{J}$, and $\mathbf{M}-P ; 200 \mu \mathrm{m}$ on all others. Abbreviations: bf, biforine or biforine-like cell; $\mathrm{dr}$, druse; fl, fi lament; pb, pigmented body; po, pollen; pr, prism; rb, raphide bundle; others as in Figure 1 from reference [88]". 
CaOx crystals in raphide shape are obtained in Lemna minor or duckweed, in both the root cap and the root proper [86]. In a study performed in leaves of 14 species of the Araceae family, i.e., Aglaonema modestum, Anthuriun andreanum, Arisaema atrorubens, Colocasia esculenta, Dieffenbachia maculata, Hydrisme rivieri, Monstera deliciosa, Philodendron fenzlii, Pisita stratiotes, Scindapsus aureus, Spathiphyllum commutatum, Symplocarpus foetidus, Syngonium podophyllum, and Zantedeschia aethiopica, it was found that they formed $\mathrm{CaOx}$ crystals with four types of morphologies: druses, raphides, prisms, and sand. Another species of this family is Amorphophallus titanum, commonly known as titan arum, its flower has been deemed the largest flower in the world, as it can measure up to $3.06 \mathrm{~m}$ in height (Figure 6A-C [89] and Figure 6D [90]). In this species, the morphology of the CaOx crystals in the inflorescence has also been determined as clusters, raphides, and slender raphides, stout (Figure 7) [89].
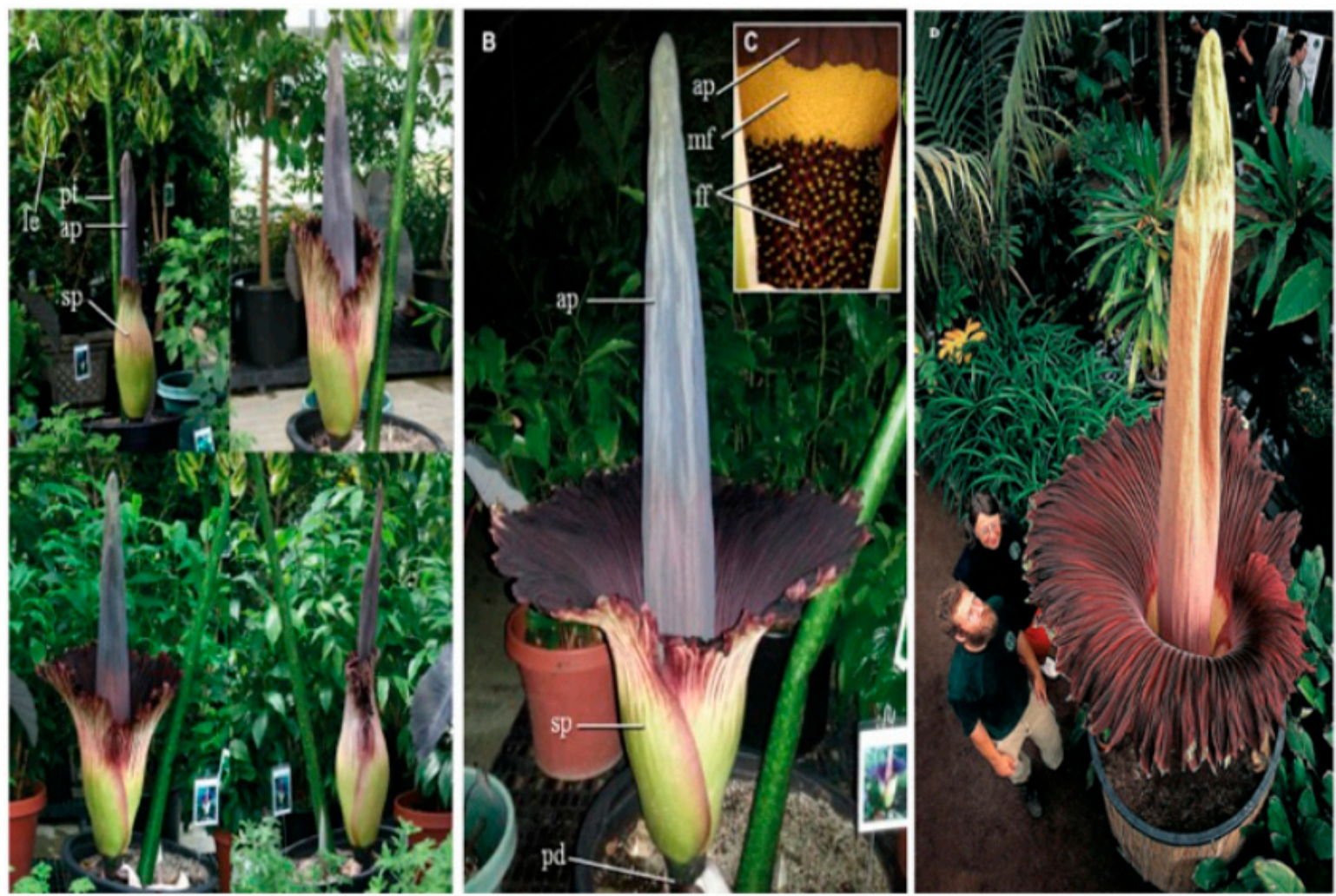

Figure 6. Amorphophallus titanum, species of the Araceae family Figure 6 A-C (original Figure 1 from Raman et al., 2017 [89]) reproduced with permission. Figure 6D (original Figure 1 from Barthlott et al., 2009 [90]) with permission. Original figure legend: “Pictures of Amorphophallus titanum inflorescence. A-Stages of titan arum flowering; B-fully opened inflorescence; C-lower part of spathe cut open to show the stamens and carpels (representing male and female flowers, respectively) studded on the lower part of the spadix. ap- appendix, ff- female flowers/carpels, le- leaf, mf- male flowers/stamens, pd-peduncle, pt- petiole, sp- spathe [89]; D-A world record flower: the fountain-like inflorescence of a Titan arum with a height of $3.06 \mathrm{~m}$ in the Botanical Gardens Bonn in May 2003. This very plant produced three simultaneous inflorescences in May 2006 (see Figure 2)". [90]. 

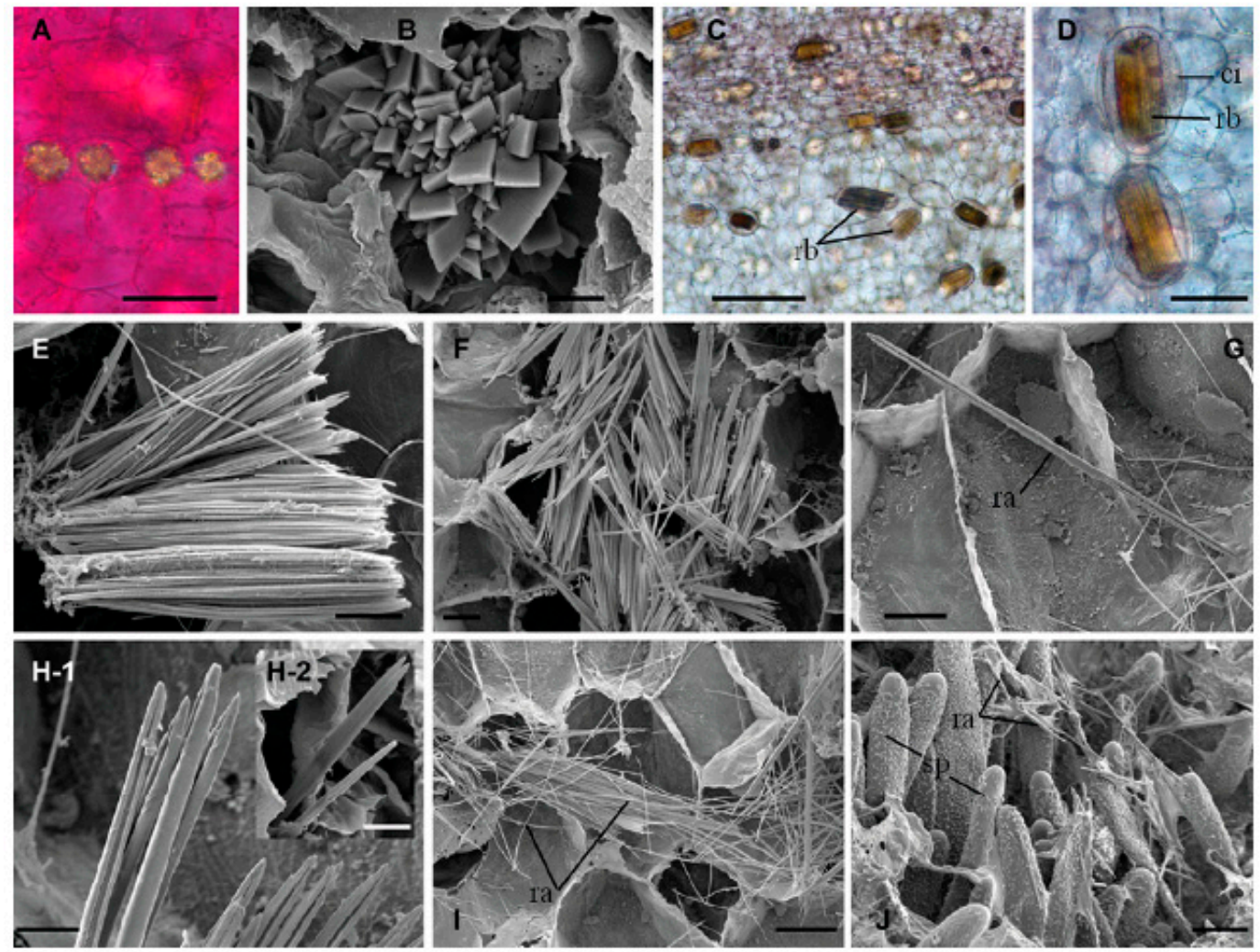

Figure 7. CaOx crystals in Amorphophallus titanium. (A,B) Cluster crystals. C-J) Raphides. (E,F) Slender raphides. (G-J) Lemna type needles (all images of crystals are from the original Figure 5 from Raman et al., 2017 [89]), reproduced with permission. Original figure legend: "Crystals of calcium oxalate in Amorphophallus titanum inflorescence (A: polarized light microscopy; C,D: light microscopy; B,E-J: SEM]. Cluster crystals $(\mathbf{A}, \mathbf{B})$ and raphides $(\mathbf{C}-\mathbf{J})$ are common in the spathe and female flowers. Slender raphides of Psychotria type (E,F) and stout, Lemna type needles (G-J) are observed in the female flowers. Image J shows raphide crystals dispersed in the stigmatic fluid. ci- crystal idioblast, ra- raphide crystal, $\mathrm{rb}$ - raphide bundle, sp- stigmatic papillae. Bars: $\mathbf{A}, \mathbf{D}=50 \mu \mathrm{m} ; \mathbf{B}, \mathbf{I}=5 \mu \mathrm{m} ; \mathbf{C}=200 \mu \mathrm{m} ; \mathbf{E}, \mathbf{G}, \mathbf{H}, \mathbf{F}, \mathbf{J}=20$ $\mu \mathrm{m} "$.

In the Xanthosoma species and in Colocasia spp., CaOx crystals with a morphology of raphide bundles and intra-amylar crystals have been identified. Crystals were present in all organs of the plant [91]. The fact that the species of this family present one or another morphotype and polymorph indicates that the biomineralization process for their protection against the environment and their ability to adapt to their natural habitat are characteristic of each species, independently of the family to which they pertain.

Plants have evolved for many years and are one of the most efficient organisms on Earth that are able to produce their own food taking light, water and some nutrients from soils. The mechanism about calcium availability related to light exposure and oxalate anions produced from biochemical processes open the possibility to investigate the effect of light and their role on the growth and form.

\section{Morphological Chirality of Calcium Oxalate Crystals and Crystallographic Data}

The stereochemistry is one of the areas of chemical research that allows to synthesize organic molecules called enantiomers that, when comparing two crystals or two structures, they are mirror images of each other. This chemical approach in synthesis lays on the fundamentals of modern Chemistry. For shapes or molecular structures with the same composition, which cannot be super-imposable by any of the two properties of symmetry namely translation or rotation, this is the definition of chirality. It is worth mentioning that the chiral structure is not the same as the 
chiral morphology. In general, a chiral molecule will develop a chiral morphology in the crystal shape. However, there are some molecules that are achiral in solution and become chiral in the solid state (during crystal formation). These crystals develop chiral morphologies with hemihedral faces. In plants, calcium oxalate an achiral molecule is one of the examples of this latter situation [92]. It is clear, from the crystallographic point of view, that the crystal morphology does not reflect the molecular symmetry. In some particular cases for crystals produced in specialized cells (idioblasts) throughout the biomineralization processes the chirality can be induced by the presence of proteins, polysaccharides [93,94] or different additives [95]. In the biomineralization processes, it is common to observe biominerals that often exhibit chiral shapes. There are some investigations using atomic force microscopy (AFM) that have used some synthetic amino acids as additives in the crystal growth of calcium oxalate that have demonstrated the obtaining of two enantiomers, which have different binding preferences to steps that are related by mirror symmetry. This contribution using AFM was based on the hypothesis that the introduction of chiral molecules causes different stereochemical matching between these amino acids and the mirror symmetry-related features present on the growing surfaces [96]. On the other hand, calcium oxalate is synthesized in more than 200 plant families. The different shapes and obtainment of specific morphologies have been theoretically predicted for calcium oxalate monohydrate (whewellite) as well as for the specific evolution of those faces [97]. From the crystallographic point of view, calcium oxalate biominerals used to crystallize in two main space groups. The monoclinic whewellite ( $\mathrm{CaOx}$ monohydrate form) with the space group $\mathrm{P} 2_{1} / \mathrm{c}$ is the kinetically form usually obtained when the plant has been exposed to highly stressful situations or high supersaturation of calcium and oxalate ions. This monoclinic form has the following cell parameters: a $=6.290 \AA, b=14.583 \AA, c=10.116 \AA, \AA \alpha=90^{\circ}, \beta=109.46^{\circ}, \gamma=90^{\circ}$. On the other hand, the tetragonal phase weddellite ( $\mathrm{CaOx}$ dihydrate form) with space group $\mathrm{I} 4 / \mathrm{m}$ is mostly obtained in diffusion control in plants and it is the thermodynamically stable phase. The cell parameters of the tetragonal crystal are $\mathrm{a}=12.375 \AA, \mathrm{b}=12.375 \AA, \mathrm{c}=7.377 \AA, \AA \alpha=\beta=\gamma=90^{\circ}$ [98].

\section{The New Trends in Biomineralization Processes, the Role of Photoreceptors into Calcium Uptake, and Their Influence on Growth of Plants and Form}

In plants, visible light stimuli, for calcium accumulation in vacuoles, are converted into biological signals by photoreceptor proteins, usually called phototropins [99]. This photoreception produces the homeostasis of calcium in vacuoles. It is well known that phototropism involves a directional growth of plants, toward or away from a light source in function of the intensity of the incident electromagnetic radiation. There are different responses of the plants to light, since they are able not just to detect the presence or absence of light, but also its quality, quantity, direction and duration. Photoreceptors more commonly identified are phytochromes (PHY), cryptochromes (CRY), and phototropins (PHOT).

In Arabidopsis thaliana, it has been identified 13 photoreceptors, consisting of 5 PHY (A to E), two CRY (1 and 2), two PHOT (1 and 2), and recently a single UVR8 photoreceptor [99,100]. PHY receptors are characterized for the photoreception of red/far-red light from the environment and the subsequent adaptation of the plant growth and development, some of their functions are involved in seed germination, seedling de-etiolation and shade avoidance [101]. CRY sense omnidirectional blue-light and plays an important role in photomorphogenesis such as seedling de-etiolation, and flowering induction under long-day photoperiods; moreover, CRY can also act as chemical magnetoreceptors [102,103]. The UVR8 sense UV-B light and regulates directional bending by affecting auxin signaling $[104,105]$. Phototropins are characteristic by their response to unidirectional blue-light, usually through two components phototropin-1 (PHOT1) and phototropin-2 (PHOT2), which makes more efficient the conversion of light in chemical energy through signal-transduction and oligomerization. The well-known physiological responses associated to phototropins are stomatal opening, leaf expansion and chloroplast relocation. This is a compelling research that deserves to be thoroughly studied [106]. 


\subsection{Phototropins}

The isolation of the first phototropin gene occurred in 1997 when Briggs group studied a $120 \mathrm{kD}$ plant plasma membrane-associated protein: the NPH1 [107], which was lately renamed PHOT1 [108,109]. This gene encodes a 996 amino acid protein that undergoes blue light-dependent autophosphorylation and which was demonstrated to be essential for phototropic signal-transduction pathways in Arabidopsis. PHOT1 (NP_001030814.1) is composed by two segments, the COOH-terminal region that encodes a serine/threonine kinase, which contain 11 conserved sequence motifs characteristic of protein kinases; and the $\mathrm{NH}_{2}$-terminal region, which includes two light-oxygen-voltage (LOV) domains with $\sim 110$ amino acids each. A protein sharing $~ 80 \%$ similarity with PHOT1, with a sequence of 915 amino acids, originally named NPL1 and later designed as PHOT2 (NP_001318824.1) [110,111], was demonstrated to act in a redundant manner with PHOT1, like blue-light receptors that mediate physiological responses. One of the remarkable differences between PHOT1 and PHOT2 is their photosensitivity, while the first one mediates both, root and hypocotyl phototropism in response of low-fluence rate unilateral blue light $\left(<1 \mu \mathrm{mol} . \mathrm{m}^{-2} \mathrm{~s}^{-1}\right)$, PHOT 2 exhibit normal phototropism under high-fluence rates $\left(1-100 \mu \mathrm{mol} . \mathrm{m}^{-2} \mathrm{~s}^{-1}\right)$ [111]. The response to the fluence rates in Arabidopsis is summarized as follows: Phototropins 1 and 2 are both involved in physiological and blue light fluence response [112-116].

\subsection{The Light-Oxygen-Voltage (LOVs) Domains}

The LOV domains contain two similar motif sequences of 110 amino acids, LOV1 and LOV2, and they are members of the PAS (Per, ARNT, Sim) superfamily [117]. Their structure is almost identical and comprises five antiparallel $\beta$-strands interconnected by two $\alpha$-helices. In Arabidopsis PHOT1 comprise the residues 197-300 and 475-578 for LOV1 and LOV2 respectively, and 133-236 and 389-492 for LOV1 and LOV2 for PHOT2 [118]. Crystallization of Arabidopsis phototropins, can be reviewed for LOV1 of Phot1 (2Z6c) and Phot2 (2z6d) in Nakasako research [104], where 1.2 Åand 0.8 Åresolutions were achieved, respectively. For LOV2, Phot1 (4hhd) Halavaty reach a 2.75 Åresolution, and Phot2 (4eep) was resolved at 0.9 Åfor Christie [119-126]. In spite of the structural similarities between LOV1 and LOV2, the functions they show are quite different. Christie, et al. [124] indicates that LOV2 domain act as a modulator that induces phosphorylation of the kinase domain [127], while Matsuoka, et al suggest that LOV1 control the sensitivity of light regulation of LOV2 [104]. Besides that, LOV1 is thought to act as a dimerization site as stablished by Nakasako et al [120]. Studies realized by Oide et al shows that both, LOV1 and LOV2, contribute to the kinase activity and blue light conformational changes in PHOT2 [121]. Moreover, it has been shown that quantum efficiencies of the photoreaction are 10 and 2 times higher in LOV2 domain than in LOV1 [122,123].

\subsection{The Flavin Mononucleotide Molecule and the Photocycle}

The photoactivation of phototropins is mediated by the chromophore Flavin mononucleotide (FMN) [108]. Each of the two LOV sensing domains found in the $\mathrm{NH}_{2}$-terminal half of the protein bind stoichiometrically and non-covalently the FMN molecule in their ground state, i.e., under dark [125]. This is known as the Dark-state or (D-sate). The maximum absorption of D-state is found at 447 $\mathrm{nm}\left(\right.$ also $\left.\mathrm{LOV}_{447}\right)$. Under light conditions, the photochemistry involved suggest the formation of an FMN-thiol C(4a) adduct with a highly conserved cysteine (Cys) residue. Arabidopsis phot1 residues are Cys-234 and Cys-512 [118,126], and phot2 residues are Cys-170 in LOV1 and Cys-426 in LOV2 [121]. The formation of the adduct functions as a molecular switch that transmits structural changes in the LOV to the kinase domain [118]. Light drives, in less than $30 \mathrm{~ns}$, the production of a highly reactive triplet-state flavin $\left(\mathrm{LOV}_{660}\right)$ which decays within $4 \mu \mathrm{s}$ and leads to formation of a covalent bond between the $\mathrm{C}(4 \mathrm{a})$ carbon of the FMN chromophore and a conserved cysteine residue within the LOV domain ( $\mathrm{LOV}_{390}$ or S-state). The photoreaction process is fully reversible in darkness. The recovery of 
LOV domains follows a first order kinetic and occurs more rapidly for LOV1 than for LOV2. The half time recovery for LOV2 is around $\sim 50 \mathrm{~s}$ [128].

\subsection{The Origin and Evolution of Phototropins}

It has been shown that phototropins are present in all major land plants lineages, as well as in green algae. In higher plants, two specialized phots are commonly found; however, it is believed that ancient organisms containing light receptors could have just one general purpose photoreceptor. That is the case of the livewort $M$. polymorpha, in which chloroplast avoidance and accumulation responses obey to the presence of a single phototropin [129]. Phototropin phylogeny investigated by Li, et al shows that the origin of phototropins is attributed to an ancestor of Viridipplantae, (land plants + green algae), since they are present in all major land plant linages as well as in green algae, but not in red algae, cryptophytes, haptophytes, or stramenopiles [130-132]. Adaptation of early land plants depended directly on the availability of water, light duration and quality, and nutrients [133].

\subsection{Calcium Uptake and Its Importance in Plant.Growth and Form}

Calcium is one of the most important elements present in a variety of biominerals in the earth's crust along with some specific anions. Calcium carbonate is present in many marine and terrestrial organisms (e.g., these species have formed shells as a way of protection against predators). Calcium sulfate is also precursor of gypsum, calcium phosphate is the main component of bones forming hydroxyapatite, calcium oxalate appears in plants as a protection against herbivory or insect attacks or even as calcium's accumulation system [134,135]. Additionally, there is a beneficial process when adding ground limestone to acids soils to increase crop yields. All plants without calcium are unable to grow or to complete their life cycles [134]. The mechanism for calcium uptake and its accumulation in vacuoles as well as in the cytosol calcium homeostasis has been scarcely investigated in the last thirty years [136]. The growth of calcium oxalate is mediated by cells; it might have genes involved in the biomineralization processes. It is important to mention that there is a critical need for correlative bio-physicochemical characterization of the full biomineralization process [49]. Additionally, there is a lack of research about the role of calcium focused on the relationship photoreceptor-interacting proteins. The photoreception is a phenomenon, which is initiated by two photoreceptors called cryptochromes 1 and 2 (CRY1, CRY2) and the non-phototropic hypocotyl 1 receptor (NPH1) as we described it on second part of this review. The end terminal region of this last receptor contains a repeated motif of 110 aa, designated Light-Oxygen-Voltage domains LOV-1 and LOV-2 as we already mentioned. These two domains of NPH1 bind flavin mononucleotide (FMN) and undergo a self-contained photocycle. The receptor NPH1 regulates the avoidance movement of chloroplasts in response to high light intensities of blue light. This receptor causes a transient increase in cytosolic $\mathrm{Ca}^{2+}$ as shown by Gross and Marmé (1978), who investigated the dependency between ATP-dependent $\mathrm{Ca}^{2+}$ accumulation in the microsomal fraction in plants [136]; this process showed that it can be controlled by white light in vitro. One of the future applications of photoreceptors from plants combining optical and genetic approaches will be the Optogenetics $[137,138]$. Nowadays, the importance of calcium as an essential element is remarkable in many organisms. The biominerals where it is present, as well as the mechanisms that explain the formation of a variety of biogenic minerals, are still under compelling investigations into the world of the biomineralization processes.

\section{Concluding Remark}

Being able to understand why some plant species present only one type of $\mathrm{CaOx}$ crystals morphology, whereas other species synthetize several morphologies and polymorphs is of crucial relevance, because it is possible that this fact can be related with the biomineralization processes performed or adapted by the plant to survive. However, above all, it will be interesting to understand how the biomineralization process is achieved by all organisms, and how this process could be the site of the chemical origin of life on Earth. There are three main biominerals that appear in plants namely 
calcium oxalate, calcium carbonate, and calcium phosphate. However, the existence of phytolites in plants is a connection with the Precambrian time, where silica structures were very common in many micro-organisms that still exist on Earth like the radiolarian and diatoms.

Our second conclusion is that the light is the most important environmental signal that regulates calcium uptake related to the growth of plants and, in some way, their form. The role of all these light receptors for both blue and red light induces changes in the membrane properties, gene expressions and over-expression of proteins and polysaccharides related to calcium salts and formation of biominerals as hybrid materials. It will be necessary in the near future to investigate the transduction pathways in calcium signaling to solve big issues in the knowledge of plant physiology and most particularly the formation of a variety of biocrystals in plants.

Author Contributions: Conceptualization, M.C.-C., A.M.; M.E.M. Methodology and writing, M.C.-C.; K.S.P.; A.M.; validation, resources, M.E.M.; writing—original draft preparation, M.C.-C.; K.S.P.; A.M.; writing-review and editing, A.M.; funding acquisition, M.C.-C.; A.M.; M.E.M.; All authors have read and agreed to the published version of the manuscript.

Funding: This research was funded by CONACYT project A1-S-7509 (A.M.), and University of Guanajuato project 009/2020 (M. C-C).

Acknowledgments: MCC dedicates this work to Herlinda Cruz Ramírez, because life is more complex than the understanding of the chemical origin of life. One of the authors (A.M.) acknowledges the support from CONACYT project A1-S-7509. M. C-C thanks Proyecto-Institucional-009/2020 from Universidad de Guanajuato, México. The authors acknowledge to Ms. Antonia Sánchez-Marín for the English revision and grammar corrections.

Conflicts of Interest: "The authors declare no conflict of interest."

\section{References}

1. Bernal, J.D. The physical basis of life. Proc. R. Soc. 1949, 257, 635-641.

2. Wachtershauser, G. Pyrite formation, the first energy source for life: A hypothesis. Syst. Appl. Microbiol. 1988, 10, 207-210. [CrossRef]

3. Keller, M.; Blochl, E.; Wachtershauser, G.; Stetter, K.O. Formation of amide bonds without a condensation agent: Implications for the origin of life. Nature 1994, 368, 836. [CrossRef]

4. James, P.F. Mineral catalysis and prebiotic synthesis: Montmorillonite-catalyzed formation of RNA. Elements 2005, 1, 145-149.

5. Orgel, L.E. Polymerization on the rocks: Theorical introduction. Orig. Life Evol. Biosph. 1998, 28, $227-234$. [CrossRef] [PubMed]

6. Gedulin, B.; Arrhenius, G. Sources and geochemical evolution of RNA precursor molecules: The role of phosphate. In Early Life on Earth; Nobel Symposium No. 84; Bengtson, S., Ed.; Columbia U.P.: New York, NY, USA, 1994; pp. 91-106.

7. Arrhenius, T.; Arrhenius, G.; Paplawsky, W.J. Archean geochemistry of formaldehyde and cyanide and the oligomerization of cyanohydrin. Orig. Life Evol. Biosph. 1994, 24, 1-19. [CrossRef] [PubMed]

8. Pitsch, S.; Eschenmoser, A.; Gedulin, B.; Hui, S.; Arrhenius, G. Mineral induced formation of sugar phosphates. Orig. Life Evol. Biosph. 1995, 25, 294-334. [CrossRef]

9. Cairns-Smith, A.G. Seven Clues to the Origin of Life; Cambridge University Press: Cambridge, UK, 1985; pp. 74-86.

10. Lowenstam, H.A. Minerals formed by organisms. Science 1981, 211, 1126-1131. [CrossRef]

11. Dubbels, B.; Dispirito, A.; Morton, J.; Semrau, J.; Neto, J.; Bazylinsky, D. Evidence for a copper-dependent iron transport system in the marine, magnetotactic bacterium strain MV-1. Microbiology 2004, 150, 2931-2945. [CrossRef]

12. Raschdorf, O.; Müller, F.D.; Pósfai, M.; Plitzko, J.M.; Schüler, D. The magnetosome proteins MamX, MamZ and MamH are involved in redox control of magnetite biomineralization in Magnetospirillum gryphiswaldense. Mol. Microbiol. 2013, 89, 872-886. [CrossRef]

13. Ruiz-Arellano, R.R.; Moreno, A. Obtainment of spherical-shaped calcite crystals induced by intramineral proteins isolated from eggshells of ostrich and emu. Cryst. Growth Des. 2014, 14, 5137-5143. [CrossRef]

14. Ruiz-Arellano, R.R.; Medrano, F.J.; Moreno, A.; Romero, A. Crystal structure of struthiocalcin-1, an intramineral protein from Struthio camelus eggshell, in two crystal forms. Acta Crystallogr. 2015, 71, 809-818. 
15. Reyes-Grajeda, J.P.; Moreno, A.; Romero, A. Crystal structure of ovocleidin-17, a major protein of the calcified Gallus gallus eggshell: Implications in the calcite mineral growth pattern. J. Biol. Chem. 2004, 279, 40876-40881. [CrossRef] [PubMed]

16. Colfen, H. Biomineralization: A crystal-clear view. Nat. Mater. 2010, 9, 960-961. [CrossRef] [PubMed]

17. Khan, S.R. Histological aspects of the "fixed-particle" model of stone formation: Animal studies. Urolithiasis 2017, 45, 75-87. [CrossRef]

18. Mann, K. The calcified eggshell matrix proteome of a songbird, the zebra finch (Taeniopygia guttata). Proteome Sci. 2015, 13, 29. [CrossRef]

19. Cuéllar-Cruz, M. Synthesis of inorganic and organic crystals mediated by proteins in different biological organisms. A mechanism of biomineralization conserved throughout evolution in all living species. Prog. Cryst. Growth Charact. Mater. 2017, 63, 94-103. [CrossRef]

20. Marin, F.; Luquet, G.; Marie, B.; Medakovic, D. Molluscan shell proteins: Primary structure, origin, and evolution. Curr. Top. Dev. Biol. 2008, 80, 209-276.

21. Rozycka, M.; Wojtas, M.; Jakob, M.; Stigloher, C.; Grzeszkowiak, M.; Mazur, M.; Ozyhar, A. Intrinsically disordered and pliable starmaker-like protein from medaka (Oryzias latipes) controls the formation of calcium carbonate crystals. PLOS ONE 2014, 9, e114308. [CrossRef]

22. Xiang, L.; Su, J.; Zheng, G.; Liang, J.; Zhang, G.; Wang, H.; Xie, L.; Zhang, R. Patterns of expression in the matrix proteins responsible for nucleation and growth of aragonite crystals in flat pearls of Pinctada fucata. PLoS ONE 2013, 8, e66564. [CrossRef]

23. Gallaher, R.N. The occurrence of calcium in plant tissue as crystals of calcium oxalate. Commun. Soil Sci. Plant Anal. 1975, 6, 315-321. [CrossRef]

24. Marín-García, L.; Frontana-Uribe, B.A.; Reyes-Grajeda, J.P.; Stojanoff, V.; Serrano-Posada, H.J.; Moreno, A. Chemical Recognition of Carbonate Anions by Proteins Involved in Biomineralization Processes and their Influence on Calcite Growth. Cryst. Growth Des. 2008, 8, 1340-1345. [CrossRef]

25. Al- Rais, A.H.; Myers, A.; Watson, L. The isolation and properties of oxalate crystals from plants. Ann. Bot. 1971, 35, 1213-1218. [CrossRef]

26. Fahn, A. Anatomía Vegetal; H. Blume Ediciones: Madrid, Spain, 1978.

27. Prasad, R.; Singh-Shivay, Y. Oxalic Acid/Oxalates in plants:from self-defence to phytoremediation. Curr. Sci. 2017, 112, 1665-1667. [CrossRef]

28. Gmelin, L.; Watts, H. Handbook of Chemistry; Cavendish Society: London, UK, 1855; Volume 9, p. 111.

29. Elejalde-Cadena, N.R.; Cuéllar-Cruz, M.; Moreno, A. The role of silica and alkaline earth metals with biomolecules in the biomineralization processes: The eggshells's formation and the crystallization in vivo for x-ray crystallography. Prog. Cryst. Growth Charact. Mater. 2020, 66, 100473. [CrossRef]

30. Faustini, M.; Nicole, L.; Ruiz-Hitzky, E.; Sanchez, C. History of Organic-Inorganic Hybrid Materials: Prehistory, Art, Science, and Advanced Applications. Adv. Funct. Mater. 2018, 28, 1704158. [CrossRef]

31. Zhang, B.; Liu, O. A method for protecting surfaces of stone material or stone-based cultural relics. Chinese Patent No. CN 1330609, 8 August 2007.

32. Sharma, Y.K.; Gilhotra, U.K. A Review on Urolithiasis. J. Biomed. Pharm. Res. 2019, 8, 50-57. [CrossRef]

33. Ensikat, H.-J.; Geisler, T.; Weigend, M. A first report of hydroxyapatite as structural biomineral in Loasaceae-plants'teeth against herbovores. Nature Sci. Reports 2016, 6, 26073.

34. Weigend, M.; Mustafa, A.; Ensikat, H.-J. Calcium Phosphate in Plant Trichomes: The Overlooked Biomineral. Planta 2018, 247, 277-285. [CrossRef]

35. Nawaz, M.A.; Zakharenko, A.M.; Zemchenko, I.V.; Haider, M.S.; Ali, M.A.; Imtiaz, M.; Chung, G.; Tsatsakis, A.; Sun, S.; Golokhvast, K.S. Phytolith Formation in Plants: From Soil to Cell. Plants 2019, 8, 249. [CrossRef]

36. He, H.; Veneklaas, E.J.; Kuo, J.; Lambers, H. Physiological and ecological significance of biomineralization in plants. Trends Plant Sci. 2014, 19, 166-174. [CrossRef] [PubMed]

37. Weiner, S.; Dove, P.M. An Overview of Biomineralization Processes and the Problem of the Vital Effect. Rev. Mineral. Geochem. 2003, 54, 1-29. [CrossRef]

38. Shimizu, M.H.; Gois, P.H.; Volpini, R.A.; Canale, D.; Luchi, W.M.; Froeder, L.; Heilberg, I.P.; Seguro, A.C. $\mathrm{N}$-acetylcysteine protects against star fruit induced acute kidney injury. Ren. Fail. 2017, 39, 193-202. [CrossRef]

39. Morton, J.F. Carambola. In Fruits of Warm Climates; Morton, J.F., Ed.; Florida Flair Books: Florida, FL, USA, 1987; pp. 125-128. 
40. Nguimezong, M.B.N.; Foba-Tendo, J.; Yufanyi, D.M.; Etape, E.P.; Eko, J.N.; Ngolui, L.J. Averrhoa carambola: A renewable source of oxalic acid for the facile and green synthesis of divalent metal ( $\mathrm{Fe}, \mathrm{Co}, \mathrm{Ni}, \mathrm{Zn}$, and $\mathrm{Cu}$ ) oxalates and oxide nanoparticles. J. Appl. Chem. 2014, 2014, 767695.

41. Ananna, M.A.; Hasan, R.; Samad, T.; Rahim, M.A.; Rahman, M.E.; Haque, W.M.; Billah, M.; Hoque, H.F. Acute kidney injury due to star fruit ingestion: A case report. Bangabandhu Sheikh Mujib Med. Univ. J. 2014, 7, 151-153. [CrossRef]

42. Monje, P.V.; Barán, E.J. Characterization of calcium oxalates generated as biominerals in cacti. Plant Physiology. 2002, 128, 707-713. [CrossRef]

43. Macnish, A.J.; Irving, D.E.; Joyce, D.C.; Vasanthe, V.A.H.; Wearing, R.I.; Webb, A.; Frost, R.L. Identification of intracellular calcium oxalate crystals in Chamelaucium uncinatum (Myrtaceae). Austral. J. Bot. 2003, 51, $565-572$. [CrossRef]

44. Jáuregui-Zuñiga, D.; Reyes-Grajeda, J.P.; Moreno, A. Modifications on the Morphology of Synthetically grown Calcium Oxalate Crystals by Crystal-associated Proteins Isolated from Bean Seed Coats (Phaseolus vulgaris). Plant Sci. 2005, 168, 1163-1169. [CrossRef]

45. Hartl, W.P.; Klapper, H.; Barbier, B.; Ensikat, H.J.; Dronskowski, R.; Müller, P.; Ostendorp, G.; Tye, A.; Bauer, R.; Barthlott, W. Diversity of calcium oxalate crystals in Cactaceae. Can. J. Bot. 2007, 85, 501-517. [CrossRef]

46. Contreras-Padilla, M.; Rivera-Muñoz, E.M.; Gutiérrez-Cortez, E.; Real, A.; Rodríguez-García, M.E. Characterization of crystalline structures in Opuntia ficus-indica. J. Biol. Phys. 2015, 41, 99-112. [CrossRef]

47. Rojas-Molina, I.; Gutiérrez-Cortez, E.; Bah, M.; Rojas-Molina, A.; Ibarra-Alvarado, C.; Rivera- Muñoz, E.; Del Real, A.; Aguilera-Barreiro, M.A. Characterization of calcium compounds in Opuntia ficus-indica as a source of calcium for human diet. J. Chem. 2015, 2015, 1-8. [CrossRef]

48. Franceschi, V.R.; Nakata, P.A. Calcium oxalate in plants: Formation and function. Annu. Rev. Plant Biol. 2005, 56, 41-71. [CrossRef] [PubMed]

49. Webb, M. Cell-mediated crystallization of calcium oxalate in plants. Plant Cell 1999, 11, 751-761. [CrossRef]

50. Franceschi, V.; Horner, H. Calcium oxalate crystals in plants. Bot. Rev. 1980, 46, 361-427. [CrossRef]

51. Franceschi, V.; Li, L.; Zhang, D.; Okita, T. Calsequestrin-like calcium binding protein is expressed in calcium accumulating cells of Pistia stratiotes. Proc. Nat. Acad. Sci. USA 1993, 90, 6986-6990. [CrossRef]

52. Volk, G.; Lynch-Holm, V.; Kostman, T.; Goss, L.; Franceschi, R. The Role of druse and raphide calcium oxalate crystals in tissue calcium regulation in Pistia stratiotes leaves. Plant Biol. 2002, 4, 34-45. [CrossRef]

53. Keates, S.; Tarlyn, N.; Loewus, F.; Franceschi, V. L-Ascorbic acid and L-galactose are sources for oxalic acid and calcium oxalate in Pistia stratiotes. Phytochemistry 2000, 53, 433-440. [CrossRef]

54. Kostman, T.; Tarlyn, N.; Loewus, F.; Franceschi, V. Biosynthesis of L-ascorbic acid and conversion of carbons 1 and 2 of L-ascorbic acid to oxalic acid occurs within individual calcium oxalate crystal idioblasts. Plant Physiol. 2001, 125, 634-640. [CrossRef]

55. Wattendorff, J. A third type of raphide crystal in the plant kingdom: Six-sided raphides with laminated sheaths in Agave americana L. Planta 1976, 130, 303-311. [CrossRef]

56. Yang, J.; Loewus, F.A. Metabolic conversion of L-Ascorbic acid in oxalate-accumulating plants. Plant Physiol. 1975, 56, 283-285. [CrossRef]

57. Bárcenas-Argüello, M.L.; Gutiérrez-Castorena, M.C.; Terrazas, T. The polymorphic weddellite crystals in three species of Cephalocereus (Cactaceae). Micron 2015, 77, 1-8. [CrossRef] [PubMed]

58. Viñas, M.; Jiménez, V.M. Occurrence and characterisation of calcium oxalate crystals in stems and fruits of Hylocereus costaricensis and Selenicereus megalanthus (Cactaceae: Hylocereeae). Micron 2016, 89, 21-27. [CrossRef] [PubMed]

59. Frausto-Reyes, C.; Loza-Cornejo, S.; Terrazas, T.; De la Luz Miranda-Beltrán, M.; Aparicio-Fernández, X.; López-Macías, B.M. Morales-Martínez, S.E. Raman spectroscopy study of calcium oxalate extracted from cacti stems. Appl. Spectrosc. 2014, 68, 1260-1265. [CrossRef]

60. López-Macías, B.M.; Morales-Martínez, S.E.; Loza-Cornejo, S.; Reyes, C.F.; Terrazas, T.; Patakfalvi, R.J. Variability and composition of calcium oxalate crystals in embryos-seedlings-adult plants of the globose cacti Mammillaria uncinata. Micron 2019, 125, 102731. [CrossRef] [PubMed]

61. Borrelli, N.; Benvenuto, M.L.; Osterrieth, M. Calcium oxalate crystal production and density at different phenological stages of soybean plants (Glycine max L.) from the southeast of the Pampean Plain, Argentina. Plant Biol. (Stuttg.) 2016, 18, 1016-1024. [CrossRef] [PubMed] 
62. Arnott, H.J.; Webb, M.A. Twin crystals of calcium oxalate in the seed coat of the kidney bean. Protoplasma 1983, 114, 23-34. [CrossRef]

63. Gulliver, G. On the crystals in the testa and pericarp of several orders of plants, and in other parts of the order Leguminosae. Mon. Micro. J. 1873, 10, 259-266. [CrossRef]

64. Rodrigues, T.M.; Machado, S.R. The pulvinus endodermal cells and their relation to leaf movement in legumes of the Brazilian cerrado. PlantBiology (Stuttgart, Germany) 2007, 9, 469-477. [CrossRef]

65. Horner, H.T.; Zindler-Frank, E. Calcium oxalate crystals cells in the leaves of Rhynchosia caribaea (Leguminosae: Papilionoideae. Protoplasma 1982, 111, 10-18. [CrossRef]

66. Jáuregui-Zuñiga, D.; Moreno-Cárcamo, A. La biomineralización del oxalato de calcio en plantas: Retos y potencial. Rev. Edu. Bioquim. 2004, 23, 18-23.

67. Jáuregui-Zúñiga, D.; Ferrer, M.A.; Caldero, A.A.; Munoz, R.; Moreno, A. Heavy metal stress reduces the deposition of calcium oxalate crystals in leaves of Phaseolus vulgaris. J. Plant Physiol. 2005, 162, 1183-1187. [CrossRef] [PubMed]

68. Duarte, M.R.; Wolf, S. Anatomical characters of the phyllode and stem of Acacia podalyriifolia A. Cunn. ex G. Don (Fabaceae). Rev. Bras. Pharmacog. 2005, 15, 71-76. [CrossRef]

69. Barnabas, A.D.; Howard, J.A. Calcium oxalate crystal formation in the bean (Phaseolus Vulgaris, L.) seed coat. Bot. Gaz. Int. J. Plant Sci. 1990, 151, 331-341. [CrossRef]

70. Zindler-Frank, E.; Wichmann, E.; Korneli, M. Cells with crystals of calcium oxalate in the Leaves of Phaseolus vulgaris-A Comparison with those in Canavalia ensiformis. Bot. Acta 1988, 101, 246-253. [CrossRef]

71. Zindler-Frank, E. Calcium oxalate crystals in legumes. In Advances in Legume Systematic, Part 3; Stirton, E., Ed.; Royal Botanic Gardens: Kew, UK, 1987; pp. 279-316.

72. Zindler-Frank, E.; Honow, R.; Hesse, A. Calcium and oxalate content of the leaves of Phaseolus vulgaris at different calcium supply in relation to calcium oxalate crystal formation. J. Plant Physiol. 2001, 158, 139-144. [CrossRef]

73. Borchert, R. Functional anatomy of the calcium excreting system of Gleditsia triacanthos L. Bot. Gaz. 1984, 145, 474-482. [CrossRef]

74. Ilarsalan, H.; Palmer, R.G.; Horner, H.T. Calcium oxalate crystals in developing seeds of Soybean. Ann. Bot. 2001, 88, 243-257. [CrossRef]

75. Nakata, P.A.; McConn, M.M. Isolation of Medicago truncatula mutants defective in calcium oxalate crystal formation. Plant Physiol. 2000, 124, 1097-1104. [CrossRef]

76. Ward, G.; Harbers, L.H.; Blaha, J.J. Calcium containing crystals in Alfalfa: Their fate in cattle. J. Dairy Sci. 1979, 62, 715-722. [CrossRef]

77. Korth, K.L.; Doege, S.J.; Park, S.H.; Goggin, F.L.; Wang, Q.; Gomez, S.K.; Liu, G.; Jia, L.; Nakata, P.A. Medicago truncatula mutants demonstrate the role of plant calcium oxalate crystals as an effective defense against chewing insects. Plant Physiol. 2006, 141, 188-195.

78. Benecke, W. Ueber Oxalsaurebildung in grunen Pflanzen. Bot. Ztg. 1903, 61, 79-110.

79. Lersten, N.R. Crystals of calcium compounds in Gramineae. New Phytol. 1983, 93, 633-637. [CrossRef]

80. Hernandéz-Valencia, R.E.M.; López-Franco, R.; Ruíz-Ordoñez, J.; Ramirez-Rodriguez, H.; Benavides-Mendoza, A. The stomatal complex and picuticular characteristics of crown rot disease of Agave tequilana weber (Agavaceae). Acta Hortic. 2003, 618, 427-433. [CrossRef]

81. Ishii, Y. Needle crystal of calcium oxalate monohydrate found in plant. J. Electron Microsc. 1992, 41, 53-56.

82. Bernardino-Nicanor, A.; Teniente-Martínez, G.; Juarez-Goiz, J.M.S.; Filardo-Kerstupp, S.; Montañez-Soto, J.L.; González-Cruz, L. Changes in the concentration and characteristics of calcium oxalate crystals during development stages of Agave atrovirens. Adv. Biores. 2012, 3, 22-28.

83. Den Outer, R.W.; Van Veenendaal, W.L.H. Gold speckles and crystals in tomato fruits (Lycopersicon esculentum Mill.). J. Hortic. Sci. 1988, 63, 645-649. [CrossRef]

84. De Kreij, C.; Janse, J.; Van Goor, B.J.; Van Doesburg, J.D.J. The incidence of calcium oxalate crystals in fruit walls of tomato (Lycopersicon esculentum Mill.) as affected by humidity, phosphate and calcium supply. J. Hortic. Sci. 1992, 67, 45-50. [CrossRef]

85. Clark, C.J.; Smith, G.S.; Walker, G.D. The form, distribution and seasonal accumulation of calcium in kiwifruit leaves. New Phytologist 1987, 105, 477-486. [CrossRef]

86. Franceschi, V.R. Calcium oxalate formation is a rapid and reversible process in Lemna minor L. Protoplasma 1989, 148, 130-137. [CrossRef] 
87. Barabé, D.; Lacroix, C.; Chouteau, M.; Gibernau, M. On the presence of extracellular calcium oxalate crystals on the inflorescences of Araceae. Bot. J. Linn. Soc. 2004, 146, 181-190. [CrossRef]

88. Coté, G.G.; Gibernau, M. Distribution of calcium oxalate crystals infloral organs of Araceae in relation to pollination strategy. Am. J. Bot. 2012, 99, 1231-1242. [CrossRef] [PubMed]

89. Raman, V.; Tabanca, N.; Demirci, B.; Khan, I. Studies on the Floral Anatomy and Scent Chemistry of Titan Arum (Amorphophallus titanum, Araceae). Turk. J. Bot. 2017, 41, 63-74. [CrossRef]

90. Barthlott, W.; Szarzynski, J.; Vlek, P.; Lobin, W.; Korotkova, N. A torch in the rain forest: Thermogenesis of the Titan arum (Amorphophallus titanum). Plant Biol. (Stuttg.) 2009, 11, 499-505. [CrossRef] [PubMed]

91. Osuji, J.O. Probable functions of calcium oxalate crystals in different tissues of the edible aroids (Xanthosoma and Colocasia spp.) in Nigeria. Afr. J. Biotechnol. 2013, 12, 3952-3956.

92. Levy-Lior, A.; Weiner, S.; Addadi, L. Achiral Calcium-Oxalate Crystals with Chiral Morphology from the Leaves of Some Solanacea Plants. Helv. Chim. Acta. 2003, 86, 4007-4017. [CrossRef]

93. Addadi, L.; Geva, M. Molecular recognition at the interface between crystals and biology: Generation, manifestation and detection of chirality at crystals surfaces. Cryst. Eng. Comm. 2003, 5, 140-146. [CrossRef]

94. Bouropoulos, N.; Weiner, S.; Addadi, L. Calcium Oxalate Crystals in Tomato and Tobbaco Plants: Morphology and in Vitro Interactions of Crystal-Associated Macromolecules. Chem. Eur. J. 2001, 7, 1881-1888. [CrossRef]

95. Liu, N.; Xie, H.; Ping, H.; Wang, L.; Liu, Z.; Tao, F.; Guo, J.; Su, B.L. Shape and structure controlling of calcium oxalate crystals by a combination of additives in the process of biomineralization. RSC Adv. 2018, 8, 11014. [CrossRef]

96. Cho, K.R.; Salter, E.A.; De Yoreo, J.J.; Wierzbicki, A.; Elhadj, S.; Huang, Y.; Qiu, S.R. Impact of Chiral Molecules on the Formation of Biominerals: A Calcium Oxalate Monohydrate Example. Cryst. Growth Des. 2012, 12, 5939-5947. [CrossRef]

97. Prywer, J. Theoretical analysis of specific evolution of some faces of plant COM crystals. Cryst. Eng. Comm. 2009, 11, 196-202. [CrossRef]

98. Jáuregui-Zúñiga, D.; Reyes-Grajeda, J.P.; Sepúlveda-Sánchez, J.D.; Whitaker, J.R.; Moreno, A. Crystallochemical characterization of calcium oxalate crystals isolated from seed coats of Phaseolus vulgaris and leaves of Vitis vinifera. J. Plant Physiol. 2003, 160, 239-245. [CrossRef] [PubMed]

99. Kharshiing, E.; Sreelakshmi, Y.; Sharma, R. The Light Awakens! Sensing Light and Darkness. In Sensory Biology of Plants; Sopory, S., Ed.; Springer Nature: Singapore, 2019; pp. 21-57.

100. Franklin, K.A.; Quail, P.H. Phytochrome Functions in Arabidopsis Development. J. Exp. Bot. 2010, 61, 11-24. [CrossRef] [PubMed]

101. Li, J.; Li, G.; Wang, H.; Wang, D.X. Phytochrome Signaling Mechanisms. Arabidopsis Book 2011, 9 , e0148. [CrossRef]

102. Ahmad, M.; Galland, P.; Ritz, T.; Wiltschko, W. Magnetic Intensity Affects Cryptochrome-dependent Responses in Arabidopsis thaliana. Planta 2007, 225, 615-624. [CrossRef] [PubMed]

103. Rizzini, L.; Favory, J.; Cloix, C.; Faggionato, D.; O’Hara, A.; Kaiserli, E. Perception of UV-B by the Arabidopsis UVR8. Protein Sci. 2011, 332, 103-106.

104. Vanhaelewyn, L.; Va Der Streaten, D.; Vandenbussche, F. Determination of Photropism by UV-B Radiation. In Phototropism. Methods and Protocols. Methods in Molecular Biology; Springer Nature: Singapore, 2019; Volume 1924.

105. Vandenbussche, F.; Tilbrook, K.; Fierro, A.C.; Poelman, D.; Van Der Straeten, D.; Ulm, R. Photoreceptor-mediated Bending towards UV-B in Arabidopsis. Mol. Plant 2014, 7, 1041-1052. [CrossRef]

106. Christie, J.M. Phototropin Blue-Light Receptors. Ann. Rev. Plant. Biol. 2007, 58, 21-45. [CrossRef]

107. Huala, E.; Oelle, P.W.; Liscum, E.; Han, I.-S.; LArsen, E.; Briggs, W.R. Arabidopsis NPH1: A Protein Kinase with a Putative Redox-Sensing Domain. Science 1997, 278, 2120-2123. [CrossRef]

108. Christie, J.M.; Salomon, M.; Nouze, K.; Wada, M.; Briggs, W.R. LOV (Light Oxygen, or Voltage) Domains od the Blue-light Receptor Phototropin (NPH1): Binding Sites for the FMN Chromophore Flavin Mononucleotide. Proc. Natl. Acad. Sci. USA 1999, 96, 8779-8783. [CrossRef]

109. Briggs, W.R.; Beck, C.F.; Cashmore, A.R.; Christie, J.M.; Hughes, J.; Jarillo, J.A.; Kawaga, T.; Kanegae, H.; Liscum, E.; Nagatami, A.; et al. The Phototropin Family of Receptors. Plant Cell 2001, 13, 993-997. [CrossRef]

110. Sakai, T.; Kagawa, T.; Kasahara, M.; Swartz, T.E.; Christie, J.M.; Briggs, W.R.; Wada, M.; Okada, K. Arabidopsis NPH1 and NPL1: Blue-light Receptors that Mediate both Phototropism and Chloroplast relocation. Proc. Natl. Acad. Sci. USA 2001, 12, 6969-6974. [CrossRef] 
111. Jarillo, J.A.; Gabrys, H.; Capel, J.; Alonso, J.M.; Ecker, J.R.; Cashmore, A.R. Phototropin-related PNL1 Controls Chloroplast Relocation Induced by Blue Light. Nature 2001, 410, 952-954. [CrossRef]

112. Sakai, T.; Wada, T.; Ishiguro, S.; Okada, K. RTP2: A Signal Transducer of the Phototropic Response in Arabidopsis. Plant Cell 2000, 12, 225-236. [CrossRef] [PubMed]

113. Crosson, S.; Moffat, K. Photoexcited Structure of a Plant Photoreceptor Domain Reveals a Light-driven Molecular Switch. Plant Cell 2002, 14, 1067-1075. [CrossRef]

114. Kagawa, T.; Sakai, T.; Suetsugu, N.; Oikawa, K.; Ishiguo, S.; Kato, T.; Tabata, S.; Okada, K.; Wada, M. Arabidopsis PNL1: A Phototropin Homolog Controlling High-light Avoidance Response. Science 2001, 291, 2138-2141. [CrossRef] [PubMed]

115. Kinoshita, T.; Doi, M.; Suetsugu, N.; Kugawa, T.; Wada, M.; Shimazaki, K.-I. PHO1, PHO2 Mediate Blue Light Regulation of Stomatal Opening. Nature 2001, 414, 656-660. [CrossRef] [PubMed]

116. Lin, C. Phototropin Blue Light Receptors and Light-induced Movement Responses in Plants. Sci. STKE 2002, 118, 1-3. [CrossRef] [PubMed]

117. Taylor, B.L.; Zhulin, I.B. PAS Domain: Internal Sensors of Oxygen, Redox Potential, and Light. Microbiol. Mol. Biol. Rev. 1999, 36, 479-506. [CrossRef]

118. Nakasako, M.; Hirata, M.; Shimizu, N.; Hosokawa, S.; Matsukoa, D.; Oka, T.; Yamamoto, M.; Tokutomi, S. Crystallization and Preliminary X-ray Diffraction Analysis of the LOV1 Domains of Phototropin 1 and 2 from Arabidopsis thaliana. Acta Cryst. 2008, F64, 617-621.

119. Matsuoka, D.; Tukomi, S. Blue Light-regulated Molecular Switch of Ser/Thr Kinase in Phototropin. Proc. Natl. Acad. Sci. USA 2005, 102, 13337-13342. [CrossRef]

120. Nakasako, M.; Iwata, T.; Matsuoka, D.; Tukomi, S. Light-Induced Structural Changes of LOV-Domain-Containing Polypeptides from Arabidopsis Phototropin 1 and 2 Studied by Small-Angle X-Ray Scattering. Biochemistry 2004, 43, 14881-14890. [CrossRef] [PubMed]

121. Oide, M.; Okajima, K.; Nakagami, H.; Kato, T.; Sekigushi, Y.; Oroguchi, T.; Hikima, T.; Yamamoto, M.; Nakasako, M. Blue Light-excited LOV1 and LOV2 Domains Cooperatively Regulate the Kinase Activity of Full Length Phototropin2 from Arabidopsis. J. Biol. Chem. 2018, 293, 963-972. [CrossRef] [PubMed]

122. Kasahara, M.; Kagawa, T.; Oikara, K.; Suetsugu, N.; Miyao, M.; Wada, M. Chloroplast Movement Reduces Photodamage in Plants. Nature 2002, 420, 829-832. [CrossRef]

123. Iwata, T.; Nozaki, D.; Tokutomi, S.; Kandori, H. Comprarative Investigation of the LOV1 and LOV2 Domains is Adiantum Phytochrom3. Biochemistry 2005, 44, 7427-7434. [CrossRef]

124. Christie, J.M.; Reymond, P.; Powell, G.K.; Bernasconi, P.; Raibekas, A.A.; Liscum, E.; Briggs, W.R. Arabidopsis NPH1: A Flavoprotein with the Properties of a Photoreceptor for Phototropism. Science 1998, 282, 1698-1701. [CrossRef]

125. Salomon, M.; Christie, J.M.; Knieb, E.; Lempert, U.; Briggs, W.R. Photochemical and Mutational Analysis of the FMN-binding Domains of the Plant Blue Light Receptor, Phototropin. Biochemistry 2000, 39, 9401-9410. [CrossRef] [PubMed]

126. Halavaty, A.S.; Moffat, K. Coiled-coil Dimerization of the LOV2 Domain of the Blue-Light Phototropin 1 from Arabidopsis thaliana. Acta Cryst. 2013, F69, 1316-1321.

127. Christie, J.M.; Hitomi, H.; Arvai, A.S.; Hartfield, K.A.; Mettlen, M.; Pratt, A.J.; Tainer, J.A.; Getzoff, E.D. Structural Tunning of the Fluorescence Protein iLOV for Improved Photostability. J. Biol. Chem. 2012, 287, 22295-22304. [CrossRef] [PubMed]

128. Swartz, T.E.; Corchnoy, S.B.; Chirstie, J.M.; Lewis, J.W.; Szundi, I.; Brigg, W.R.; Bogomolni, R.A. The Photcycle of a Flavin-binding Domain of the Blue Light Photoreceptor Phototropin. J. Biol. Chem. 2001, 276, 35493-36500. [CrossRef]

129. Komatsu, A.; Terai, M.; Ishisaki, K.; Suetsugu, N.; Tsuboi, H.; Nishihama, R.; Yamato, K.T.; Wada, M.; Kohchi, T. Phototropin Encoded by a single-Copy Gene Mediates Chloroplast Photorelocation Movements in the Liverwort Merchantia polymorpha. Plant Physiol. 2014, 166, 411-427. [CrossRef]

130. Li, F.-W.; Rothfels, C.J.; Melkonian, M.; Villarreal, J.C.; Stevenson, D.W.; Graham, S.W.; Wong, G.K.-S.; Mathews, S.; Pryer, K.M. The Origin and Evolution of Phototropins. Front. Plant Sci. 2015, 6, 637. [CrossRef] [PubMed]

131. Roy, S.; Kulshrestha, K. Controlling Light with Light in Blue-light Plant Photoreceptor Phototropin. Curr. Sci. $2007,92,9$. 
132. Oide, M.; Okijama, K.; Kashojiya, S.; Takayama, K.; Oroguchi, T.; Hikima, T.; Yamamoto, M.; Nakasako, M. Blue Light-excited Light-oxygen-voltage-sensing Domain 2 (LOV2) Triggers a Rearrengement of the Kinase Domain to Induce Phosphorylation Activity in Arabidopsis Phototropin1. J. Biol. Chem. 2016, 291, 19975-19984. [CrossRef] [PubMed]

133. Schieppers, J.; Vogt, J. Setting the PAS, the Role of Circadian PAS Domain Proteins during Environmental Adaptation in Plants. Front. Plant Sci. 2015, 6, 513.

134. Pilbeam, D.J.; Morley, P.S. Calcium. In Handbook of Plant Nutrition, 2nd ed.; Barker, A., Pilbeam, D.J., Eds.; CRC Press: Boca Raton, FL, USA, 2006; pp. 121-140.

135. Nakata, P.A. An Assessment of Engineered Calcium Oxalate Crystals Formation on Plant Growth and Development as a Step toward Evaluating its Use to Enhance Plant Defense. PLoS ONE 2015, 10, 1-15. [CrossRef] [PubMed]

136. Gross, J.; Marmé, D. ATP-dependent $\mathrm{Ca}^{2+}$ Uptake into Plant Membrane Vesicles. Proc. Natl. Acad. Sci. USA 1978, 75, 1232-1236. [CrossRef] [PubMed]

137. Christie, J.M.; Gawthorne, J.; Young, G.; Fraser, N.J.; Roe, A.J. LOV to BLUF: Flavoprotein Contributions to the Optogenetic Toolkit. Mol. Plant 2012, 19, 1-12. [CrossRef]

138. Banerjee, S.; Mitra, D. Structural Basis of the Design and Engineering for Advanced Plant Optogenetics. Trends Plant. Sci. 2020, 25, 35-65. [CrossRef]

(C) 2020 by the authors. Licensee MDPI, Basel, Switzerland. This article is an open access article distributed under the terms and conditions of the Creative Commons Attribution (CC BY) license (http://creativecommons.org/licenses/by/4.0/). 